\title{
PONDERAÇÕES ACERCA DA IDEOLOGIA NO E DO ESPAÇO TURÍSTICO
}

\section{Rodrigo Meira Martoni ${ }^{1}$}

\section{Resumo}

$\mathrm{O}$ artigo trata de componentes ideológicos envolvendo os seus papéis na produção do espaço pelo turismo. Ao se questionar de onde vem o poder da ideologia, é realizada uma análise acerca de três concepções dessa categoria. A primeira aponta a ideologia como inversão e parcialidade em um processo histórico-social que se complementa, tanto para transformar a subjetividade em objetividade, como para tratar a aparência das coisas como se fossem totalidades. A segunda noção refere-se a ideologia como posicionamento de classe, abarcando alguns grupos que atuam (de maneira deliberada e/ou irrefletida) na mistificação e naturalização dos processos socioespaciais, e outros que, norteados por procedimentos que lhes permitem reproduzir idealmente a realidade, cumprem o importante papel de desmistificar os primeiros. Associada a essas noções que posicionam as ideologias no espaço alcançado pelo turismo, está a terceira concepção mais fundamental. Essa contempla a ideologia como algo enraizado às operações socioprodutivas reificadas ou do espaço turistificado, as quais não podem ser modificadas qualitativamente sem a supressão da relação cada vez mais contraditória entre capital versus trabalho. Por meio dessa análise que auto-implica as diferentes e complementares concepções, verifica-se que o turismo é um importante mecanismo de alienação, seja pelas aparências tão necessárias à circulação, seja pela forma como é produzido.

Palavras-chave: Ideologia; Capital; Turismo; Produção do espaço.

\footnotetext{
1 Professor adjunto no Departamento de Turismo da Universidade Federal de Ouro Preto. E-mail: rodrigomartoni@gmail.com
} 


\title{
WEIGHTINGS ABOUT THE IDEOLOGY IN AND OF THE TOURIST
} SPACE

\begin{abstract}
The present article adresses the ideological components and its position in the production of space by tourism. Questioning from where comes the power of ideology, an analysis is conducted about the three conceptions that compose this category. The first conception points the ideology as an inversion and with parciality in a historical-social process that is complemented by itself, both to transform the subjetivity in objectivity and to treat the appearence of things in its totalities. The second one makes reference to ideology as a class position, covering some groups which act (deliberately or thoughtlessly) for the mystification and naturalization of socio-spatial processes, and others that, guided by procedures that permit to reproduct ideally the reality, fulfill the important role of desmistify those first groups. The third and even more fundamental conception is associated with these notions that position the ideologieson the space reached by tourism. It contemplates ideology as something rooted in the socio-productives operations, reified or even of the touristic space. These operations can not be changed without the suppression of the contradictory conection between capital versus work. Through this analysis, which implies diferent and complementary conceptions, it is possible to verify tourism as an important alienation mechanism because of its appearance and the way it is produced as well.
\end{abstract}

Keywords: Ideology; Capital; Tourism; Production of space.

\section{PONDERACIONES DE LA IDEOLOGÍA EN EL Y DEL ESPACIO TURÍSTICO}

\section{Resumen}

El artículo se ocupa de los componentes ideológicos involucrando sus roles en la producción del espacio por el turismo. Al se plantear de dónde viene el poder de la ideología, se realizó un exame al respecto de tres nociones de esta categoria. La primera comprende la ideología como la inversión y la parcialidad en un proceso histórico-social que se complementa, tanto para transformar la subjetividad en la objetividad, cómo para tratar el aspecto de las cosas como totalidades. La segunda noción se refiere a la ideología como un posicionamiento de clase, que abarca algunos grupo que actúan 


\section{PONDERAÇÕES ACERCA DA IDEOLOGIA NO E DO ESPAÇO TURÍSTICO Rodrigo Meira Martoni}

(de manera deliberada y/o irreflexiva) en la mistificación y la naturalización de los procesos socio-espaciales, y otros que, guiados por los procedimientos que les permiten reproducir idealmente la realidad, cumplen el importante papel de desmitificación de la ideología de los primeros. Asociado a estas nociones que posicionan las ideologías en el espacio alcanzado por el turismo, está la tercera concepción más esencial. Esto incluye la ideología como algo arraigado a las operaciones socioproductivas cosificadas o de lo espacio turistificado, que no pueden ser modificadas cualitativamente sin la supresión de la relación cada vez más contradictoria entre el capital versus el trabajo. A través de esta análisis que involucra a los diferentes y complementarios conceptos, se puede verificar que el turismo es un importante mecanismo de alienación, tanto por las apariencias que se requierem para la circulación, como por la forma como es producido.

Palabras clave: Ideologia; Capital; Turismo; Producción del espacio.

Naturalmente, aqueles que aceitam de modo imediato a ideologia dominante como a estrutura objetiva do discurso "racional" e "erudito" rejeitam como ilegítimas todas as tentativas de identificar os pressupostos ocultos e os valores implícitos com que está comprometida a ordem dominante. Assim, em nome da "objetividade" e da "ciência", eles precisam desqualificar o uso de algumas categorias vitais do pensamento crítico. Reconhecer a legitimidade de tais categorias seria aceitar o exame dos próprios pressupostos que são assumidos como verdadeiros, juntamente com as conclusões que podem ser - e efetivamente o são - facilmente delas extraídas (MÉSZÁROS, 2004, p. 58).

[...] Assim, a sensação existe sem a "substância", isto é, o pensamento existe sem o cérebro! Será que existem de facto (sic) filósofos capazes de defender esta filosofia desmiolada? Existem! (LÉNINE, 1982, p. 37).

O que é especificamente ideológico na burguesia é sua incapacidade de compreender a estrutura da formação social como um todo por causa dos efeitos nefastos da reificação. A reificação fragmenta e desloca nossa experiência social, de modo que, sob sua influência, esquecemos que a sociedade é um processo coletivo e passamos a vê-la meramente como este ou aquele objeto ou instituição isolados (EAGLETON, 1997, p.90). 


\section{PONDERAÇÕES ACERCA DA IDEOLOGIA NO E DO ESPAÇO TURÍSTICO \\ Rodrigo Meira Martoni}

\section{Considerações Introdutórias}

Para fins ilustrativos, podemos comparar a ideologia à nossa capacidade de enxergar, considerando que a luz e as imagens que atravessam a córnea, a iris e o cristalino possuem uma única realidade. Tal realidade pode ser ou não deturpada antes de chegar à retina e ao cérebro e, nessa metáfora, tanto o vigor e a precisão do conjunto ótico, como as patologias para a cegueira que predomina em nossa sociedade (tal como evidenciou José Saramago), estão subordinados a um exame apurado acerca das diferentes ideologias. Isso envolve seus fundamentos e modos de operar, seja no que concerne aos grupos que, empanzinados de ideologia, se auto intitulam isentos ou neutros ideologicamente, seja daqueles que se valem de uma ideologia movida pelas evidências essenciais dos fatos. Afinal, " [...] tudo está 'impregnado de ideologia', quer a percebamos, quer não" (MÉSZÁROS, 2004, p. 57). Vejamos: em um artigo acerca da mão de obra requerida no setor de turismo e de suas especificidades de qualificação, publicado no último anuário da Revista Exame, um fragmento pode ser destacado: “[...] o Marriot, que opera dois resorts em Costa do Sauípe, a 80 quilômetros de Salvador, enfrentou um [grande] problema. A maioria de seu corpo de empregados foi recrutada numa comunidade que vivia basicamente da pesca. No início da escolha dos funcionários, verificou-se que eles tinham dificuldades para usar sanitários e não costumavam calçar sapatos" (IHA, 2007, p.76)².

Tal frase, à primeira vista, nada tem de ideológica, mas o que lhe dá esse tom é o veículo de comunicação onde foi impressa e, paralelamente, os comentários complementares, tais como: "parece altamente injusto que a iniciativa privada, além de gerar emprego e pagar impostos, ainda tenha de tirar do próprio bolso para conseguir funcionários com um padrão mínimo de qualificação, 'afinal, educação é um dos deveres do Estado'" (IHA, 2007, p. 76). Muito embora essa simples colocação já demonstre a avidez de uma classe sobre outra, Eagleton (1997, p. 22) explica que "não se pode decidir se um enunciado é ideológico ou não examinando-o isoladamente do seu contexto discursivo, [de forma que] a ideologia tem mais a ver com a questão de quem está falando o quê, com quem e com que finalidade [...]". Na primeira frase, se a questão do "problema" para a rede Marriot fosse posta com um sentido irônico e publicada exatamente como apresentada em uma revista, digamos, a Caros Amigos, todo o teor ideológico seria alterado. $\mathrm{O}$ mesmo vale para o trecho que se refere à educação como um

\footnotetext{
2 Aproximadamente um ano após a publicação do artigo intitulado "O desafio da mão-de-obra" (sic), a Marriot deixou de operar os dois hotéis no complexo Sauípe. Disponível em: http:// www.presstur.com/site/news.asp?news=14498. Acesso em: 20 set. 2015.
} 
dever do Estado, o qual é um fragmento que atende aos interesses específicos da referida matéria, mas não ao posicionamento liberalconservador do meio de comunicação em questão que vê o seu potencial para ser cada vez mais absorvida pelo e para o capital.

Da mesma forma, as instituições não podem ser analisadas por elas mesmas: entre as décadas de 1920 e 1930 são criados na Itália e na Alemanha órgãos governamentais para viabilizar e cuidar do lazer e das viagens das classes trabalhadoras: "En Italie, le décret-loi du 1er mai 1925 marque la naissance de l'Opera Nazionale del Dopolavoro' $[\ldots]^{3}$. Na Alemanha, a Associação Alemã dos Trabalhadores é criada em 1933 e, associada a ela, "le 27 novembre l'organisation des loisirs 'Nach der Arbeit' [...] fut fondée. Quelque temps plus tard, elle s'intitula [...] 'La Force par la Joie'" (RICHEZ; STRAUSS, 1995, p. 501-502)4. Responsáveis por promover e facilitar o acesso à peças teatrais, excursões aos finais de semana, competições esportivas, viagens de férias e cruzeiros marítimos, o viés ideológico de tais instituições vêm à tona quando vinculadas aos ditames dos partidos fascista e nazista, os quais permeavam todas essas práticas pela doutrinação política contra o comunismo, a socialdemocracia e, mais fundamentalmente, contra a consciência de classe - e era esse o sentido de socialismo que contemplava a socialização dos lazeres dos partidos únicos.

Eagleton (1997, p. 22) evidencia que a ideologia "é mais uma questão de 'discurso' que de 'linguagem'": se há uma diferença gritante em termos ideológicos entre, por um lado, as opiniões da extrema direita ou de um representante do fascismo e, por outro, de um líder da classe trabalhadora, no que se refere à linguagem isso até pode ser significativo, mas ocupa posição secundária ante o discurso. Tal lugar, obviamente, não pode ser menosprezado sob o risco de se comprometer ou mesmo de se gerar certa confusão com o uso de alguns grupos de palavras, envolvendo diferentes ideologias em campos de estudo específicos e vertentes políticas contrárias. Por exemplo: com a publicação do Relatório Brundtland ${ }^{5}$ em 1987, diversas ciências e o senso comum se apropriaram do adjetivo sustentável que, por esse documento, foi absorvido e popularizado ideologicamente, sendo que o seu sentido em obras como a de István Mészáros (2007, p.190), que significa o "controle dos processos sociais, econômicos e culturais vitais" somente possíveis com a superação do capital e do capitalismo, é radicalmente diferente daquele utilizado e propagado por indivíduos com

3 “Na Itália, o decreto-lei de $1^{\circ}$ de maio de 1925 marca o nascimento da ‘Obra Nacional para depois do trabalho $[\ldots]^{\prime \prime}$.

4 “Em 27 de novembro [de 1933, na Alemanha], a organização dos lazeres 'Depois do Trabalho' foi fundada. Algum tempo depois, ela passa a se denominada Força pela Alegria".

${ }^{5}$ Trata-se da Comissão mundial sobre meio ambiente das Organizações das Nações Unidas (ONU). O documento busca uma conciliação entre desenvolvimento capitalista e sustentabilidade, o qual somente pode encontrar respaldo na Economia Neoclássica com sua teoria marginalista, mas não no mundo real. Não é por outro motivo que Renato Santos de Souza (2000), ao apresentar a evolução dos debates em relação a questão ambiental, chama tal conceito de "modelo hegemônico de desenvolvimento sustentável" ou "desenvolvimento sustentável de mercado". Observa-se no campo do turismo a apropriação e o uso indiscriminado do termo, ou seja, sem que se saiba necessariamente de onde ele provêm e, portanto, a que propósitos efetivamente serve. 


\section{PONDERAÇÕES ACERCA DA IDEOLOGIA NO E DO ESPAÇO TURÍSTICO Rodrigo Meira Martoni}

a acepção de equilíbrio e harmonia como categorias desconexas das operacionalidades reais da forma social vigente.

Deve-se destacar, também, o papel dos espaços utilizados por grupos sociais e seus representantes, uma vez que esses podem potencializar as ideologias e seus recados: um pronunciamento denunciando o poder de manipulação da informação de uma das principais redes de televisão brasileira possui maior significação quando é feita em horário nobre na própria emissora do que em qualquer outra empresa de comunicação ${ }^{6}$.

Apesar da abrangência ou dos componentes ideológicos contidos nos discursos e vocabulários, o termo ideologia não pode referir-se a tudo e qualquer coisa sob o risco de comprometer o seu conteúdo, uma vez que "[...] qualquer palavra que abranja tudo perde o seu valor e degenera um tom vazio" (EAGLETON, 1997, p.21). Por isso, evidencia-se que é preciso identificar, utilizando-se de uma bagagem sociocultural, de meios comparativos e de dados circunstanciais, o que é efetivamente ideológico: uma conversa a respeito de mulheres que trabalham como camareiras em hotéis pode não ter conotação ideológica, mas adquire essa marca quando inclui opiniões como aquelas relacionadas aos "vastos" direitos trabalhistas brasileiros que "atrapalham" a operação empresarial quando concedem regalias como licença-maternidade de 120 dias.

Se a ideologia tem o papel de tragar contingentes para concepções de grupos sociais que detêm mais ou menos poder em certas circunstâncias, ou mesmo servem a interesses individuais que acabam circunscritos aos limites do lar, entre esses polos é preciso levar em conta que "a força do termo ideologia reside em sua capacidade de distinguir entre as lutas de poder que são até certo ponto centrais a toda uma forma de vida social e aquelas que não o são" (EAGLETON, 1997, p.21). Assim, a significação da palavra ideologia e, por extensão, o seu poder enquanto conjunto de ideias está relacionado ao nível de poder de um grupo em questão, seja ele representativo de ações políticas favoráveis ou contrárias a uma determinada situação, ou aquelas travadas no interior de um órgão governamental com as tentativas de se angariar recursos para subsetores específicos, seja, ainda, aquelas levadas a cabo por grupos feministas ou de enfrentamento ao racismo.

Deve ser considerado que, no campo das lutas ideológicas, os interesses privados permeiam os poros da esfera pública e a dominam em termos gerais, o que se estende à grande mídia. Nesse sentido, uma manifestação do movimento dos sem teto em Porto Alegre-RS ou uma paralisação de motoristas e cobradores de ônibus em São Paulo por melhores condições de trabalho, geralmente são expostos de forma pejorativa ao atrapalharem a "liberdade" e a "ordem", ao mesmo tempo em que os investimentos estruturais em áreas básicas, a carga tributária

\footnotetext{
${ }^{6}$ Refiro-me ao Jornal Nacional que foi ao ar em 15 de março de 1994, ocasião em que o apresentador Cid Moreira leu um direito de resposta concedido judicialmente ao então governador do Rio de Janeiro, Leonel Brizola.
} 


\section{PONDERAÇÕES ACERCA DA IDEOLOGIA NO E DO ESPAÇO TURÍSTICO \\ Rodrigo Meira Martoni}

proporcionalmente mais alta para os mais pobres e a manutenção da dívida pública são tratadas sem as necessárias e devidas conexões com os seus agentes fundantes: os credores do Estado. Esses condicionam a vida de milhões, mas o como e o porquê de suas operações não aparecem.

Ainda em relação ao poder da ideologia, pode-se citar um exemplo marcante, o qual, conforme evidenciou Lukács (2010, p.113), comprometeu o pensamento marxiano como "teoria universal do desenvolvimento da humanidade". Trata-se da análise fatalista que emergiu do marxismo institucional da II Internacional (1889-1914) e foi preservada pelo poder stalinista, chamada por Lukács de "vulgar" pelo fato de ter deturpado tal teoria ao afastar-se do seu conteúdo filosófico (em relação a ontologia do ser social) e do Método Dialético desenvolvido e invertido por Marx a partir de Hegel (as mediações de totalidades ou complexidades em um totalidade socioespacial dinamizada por contradições).

Ao denunciar os negativos desdobramentos dessa corrente, Netto (1981, p.20) explica que ela carrega "a noção de que a dinâmica social abriga uma lógica irrecorrível e que o social constitui uma realidade objetiva cuja estrutura obedece a uma legalidade absolutamente independente da intervenção prática sócio-humana". Netto denomina esse marxismo transformado em uma ideologia de "funcionalista", justamente por se valer de fatores que, agindo sob a dominância do econômico como ente fixador dos processos, desfaz o campo de operação dos sujeitos sociais.

Nessa vertente de entendimento, a noção de totalidade é anulada: sem ela ou desprezando-se "a relação do simples para o complexo (forma simples de valor, valor, mercadoria) [...]" (FARIA, 2011, p. 13) e a sua "interdependência entre [...] diversos aspectos" (MARX, ENGELS, 2007, p.61) envolvendo causalidades e a ação humana que pode desvendar caminhos possíveis a partir dos processos de vida reais (a forma de produção e intercâmbio), a obra de Marx seria um "sistema concluso [e não o que ela efetivamente é, ou seja], o fundamento da ontologia do ser social, [uma] teoria crítica da sociedade passível de correções, ampliações e aprofundamento" (NETTO, 1981, p. 29).

Para fins de análise em relação a categoria ideologia, convêm apontar alguns motivos e desfechos desse marxismo recortado. Quanto às motivações, Netto (1981, p. 19-27 passim) relata que o desmembramento do pensamento fundamental de Marx se deu para, 1) "legitimar um evolucionismo sociopolítico sustentado pela noção de inevitabilidade da transição socialista"; 2) impedir qualquer contestação ao poder autocrático de Stalin; e, por extensão, 3) suprimir da "critica teórica as questões referentes ao Estado, à burocracia, à cidadania, à liberdade, à vida cotidiana, etc", a qual, se efetivada e publicizada, atingiria a casta burocrática ao denunciar as desigualdades políticas e econômicas criadas por uma elite de funcionários do Estado soviético. 


\section{PONDERAÇÕES ACERCA DA IDEOLOGIA NO E DO ESPAÇO TURÍSTICO Rodrigo Meira Martoni}

Em relação às repercussões, uma foi significativa: alguns grupos, justamente pela leitura restrita das obras de Marx e com o aporte de parte de seus intérpretes, passaram a se valer ou a questionar não a teoria social por ele desenvolvida durante parte substancial de sua vida, mas, sem procurar saber, de fragmentos postos a serviço do socialismo real, ou, conforme explica Netto (1981, p. 27), de "um conjunto de representações cuja funcionalidade [era] produzir e fornecer um sistema inclusivo de normas [para convalidar] uma determinada estratégia política (de poder)"7.

Isso posto, verifica-se o poder da ideologia ao subverter a teoria marxiana colocando o capitalismo como destruidor de si independentemente das relações envolvendo as causalidades (automovimento) em conjunto com os pores teleológicos orientados à sua manutenção e aqueles efetivamente embasados em sua superação. Ao mesmo tempo, se abriu margens para o alastramento de entendimentos e ideologias que veem tal forma social como uma entidade natural, a qual sempre regulou as relações humanas e perante a qual, tal como expressou a ex-primeira ministra britânica Margareth Thatcher, não haveria alternativa.

Mas de onde vem o poder da ideologia? Trata-se somente de um componente da superestrutura que é a expressão de grupos e classes a fim de confirmar ou mesmo questionar a base produtiva e reprodutiva calcada em relações sociais de exploração para a valorização do valor, bem como os desdobramentos políticos, filosóficos e, no caso do nosso objeto de estudo, das ideias relacionadas ao turismo e à imagem dos espaços assim especificados? Feitas as considerações que propiciam uma iniciação ao que se pretende abordar - a ideologia e o seu poder no e do espaço tornado turístico - apresenta-se três abordagens marxianas a seu respeito para se tentar alcançar respostas aos questionamentos levantados. Evidencia-se que elas acompanham a análise de Marx a respeito do ser social e não são auto-excludentes.

\section{A Ideologia Como Inversão e Parcialidade}

A primeira noção de ideologia refere-se àquela relacionada a concepção idealista das coisas, qual seja, a das inversões que ocorrem tal como em uma "câmara obscura" 8 : "les idéologies sont [...] des illusons collectives, des mystifications, des représentations fausses [...] que les hommes se font d'eux-mêmes et que nous recevons toutes faites de la société où nous vivons" (ELLUL, 2012, p.260) ${ }^{9}$. Nesse sentido, as ideologias refletem o subjetivo transformado em objetivo, ou as coisas materiais e imateriais

\footnotetext{
${ }^{7}$ Netto (1980, p.19) aponta Kautsky e Plekhanov como teóricos que desenvolveram a base desse marxismo funcionalista.

${ }^{8}$ Marx e Engels se referem em "A ideologia alemã" a câmera escura como metáfora de inversão da consciência, pois o seu funcionamento, o qual é basicamente o da lente de uma máquina fotográfica, consiste em capturar a imagem por um pequeno orifício e projetá-la invertida para que seja gravada.

9 "As ideologias são as ilusões coletivas, as mistificações, as representações falsas, mas inconscientes, que os homens fazem deles mesmos e que nós recebemos inteiramente da sociedade em que vivemos".
} 


\section{PONDERAÇÕES ACERCA DA IDEOLOGIA NO E DO ESPAÇO TURÍSTICO Rodrigo Meira Martoni}

apropriadas pelos sentidos sem se efetivar a interação com seus elementos ou categorias socioespaciais constitutivas e condicionantes, as quais operam independentemente do nosso conhecimento em relação a elas.

Se nas primeiras relações sociais (o trabalho em família, nas tribos, por exemplo) "a produção das ideias, das representações, da consciência é [...] entrelaçada sem mediações com a atividade material e o intercâmbio material [...]" (MARX; ENGELS, 2007, p. 48), com o desenvolvimento das relações sociais calcadas na divisão material e intelectual do trabalho, a interação dos seres com o seu ambiente acaba cada vez mais mediada por elementos associados a concepções de mundo que não refletem necessariamente a sua práxis, sendo a consciência capaz de "representar alguma coisa sem representar algo real" (MARX; ENGELS, 2007, p. 54). Nesse processo, coloca-se ou apresenta-se caminhos analíticos que fragilizam os laços entre realidade e consciência, provocando severos efeitos reais.

Por exemplo: também sob o discurso de que o turismo é um importante mecanismo de crescimento econômico e inclusão social, foi criado no Brasil, em 1994, o Programa Nacional de Municipalização do Turismo. Desenvolvido durante as duas gestões do então presidente Fernando Henrique Cardoso, tal política pública contemplou municípios de diversas configurações, desde aqueles que contam com atributos que podem ser comercializados turisticamente ou servir de ponte para a produção de serviços (mercadorias), até os que, além de não contarem com eles, possuem a economia movimentada por setores como os de mineração e de papel e celulose, com todas as consequências socioambientais ligadas a tais atividades.

Sem disponibilizar recursos para a execução de projetos, um dos principais programas de turismo do governo federal daquele período consistiu na realização de oficinas, arquitetadas de forma que os poucos integrantes com uma visão diferenciada dos técnicos-moderadores eram intimidados e aqueles que mostravam afinidade na elaboração de propostas eram treinados e motivados para empreenderem um turismo "sustentável" em seus municípios, o qual se concretizaria pela força das ideias no que se refere à busca por recursos, a "distribuição de renda" via geração de empregos, a preservação ambiental, a redução de conflitos locais por meio da união e do consenso.

Considerava-se, então, não a realidade socioespacial para além da empiria com a produção material e imaterial e a sua devida hierarquização social, mas as boas ideias dos técnicos-mediadores e dos participantes, bem como a motivação e empreendedorismo pessoal. Verifica-se, com isso, que o falso acarreta repercussões reais e as ilusões constituem-se como eixos norteadores dos indivíduos, os quais são movidos por um suposto cientificismo que se alterna entre o positivismo e o idealismo (reacionário, não raras vezes). Voltados a questões operacionais com vistas à qualidade 


\section{PONDERAÇÕES ACERCA DA IDEOLOGIA NO E DO ESPAÇO TURÍSTICO Rodrigo Meira Martoni}

total pelo e para o mercado, ignora-se, com isso, qualquer análise ontológica e do movimento socioespacial real.

É preciso esclarecer que a referência à ideologia como representação falsa não pode ser identificada como errada, pois, por um lado, a falsidade refere-se a parcialidade do fato ou conjunto de fatos e/ou, por outro, em algo que não é verdadeiro justamente por se constituir a partir de um entendimento invertido ou com fundamentação subjetiva (ideal). A parcialidade, nesse caso, se concretiza ao se desconsiderar o Estado como instituição-suporte dos interesses das classes representativas do capital, tratando-o tão somente conforme as suas formas e funções institucionais, além de ignorar as categorias constituintes do turismo que se firmam conforme a hospitalidade torna-se cada vez mais produtiva.

Já a inversão diz respeito ao que foi mencionado anteriormente: a subjetividade que se move por ela e, portanto, com autonomia. Conforme esclarece Eagleton (1997, p. 33), deve-se considerar o falso como algo “inverídico para o caso em questão, [onde há] uma certa proporção entre proposições empíricas e aquilo que poderíamos grosseiramente denominar 'visão de mundo', na qual a última leva uma ligeira vantagem sobre as primeiras".

Por assim dizer, nessa primeira noção em que o idealismo combina-se com o empirismo, o ideólogo ou aquele sujeito que produz a ideologia não deixa de se embasar em verdades e produzir explicações até mesmo convincentes a respeito delas, mas trata-se de veracidades fragmentadas por estarem calcadas somente em "uma parcela de verdade empírica ou conceitual" (LEFEBVRE, 1999, p. 14). Afinal, para que as ideologias sejam eficazes, elas "[...] devem dar algum sentido [...] à experiência das pessoas; devem ajustar-se, em alguma medida, ao que elas conhecem da realidade social com base em sua interação prática com esta" (EAGLETON, 1997, p. 26).

Dessa forma, a ideologia como falsa consciência se justifica e opera, pois, "pelo menos uma parte daquilo que chamamos de discurso ideológico é verdadeira em um nível, mas não em outro: verdadeira em seu conteúdo empírico, mas enganosa quanto a seu valor [...]" (EAGLETON, 1997, p. 28). Trata-se de algo que possui fundamentação na observação de Marx (2008, p. 1080) de que "toda ciência seria supérflua se houvesse coincidência imediata entre a aparência e a essência das coisas".

Ao buscar distinguir "tipos" de relações entre o turismo e o território, Knafou (1996, p.72, grifo nosso) defende que "a forma mais acabada de turismo sem território, isto é, do turismo que se contenta com sítios e lugares equipados, é o turismo 'fora do solo', quase completamente indiferente à região que o acolhe e onde a extensão planejada nada mais é do que um espaço-receptáculo". Em um nível, tal colocação é procedente e corrobora críticas ao chamado "turismo idiotizante" (SANTOS FILHO, 2005, p. 37), pois se sabe que complexos de lazer como parques temáticos, resorts e até mesmo corredores turísticos (circuitos municipais, por 


\section{PONDERAÇÕES ACERCA DA IDEOLOGIA NO E DO ESPAÇO TURÍSTICO}

Rodrigo Meira Martoni

exemplo) são parcialidades elaboradas para criar certas realidades convenientes a uma estrutura de poder (produtivo e rentista).

Mas, em outro nível, trata-se de uma observação falsa, pois se desconsidera que a chamada "extensão planejada" envolve grupos sociais que interagem em atividade de trabalho para que os serviços a elas atrelados sejam realizados (vendidos): havendo domínio em relação ao que será prestado, abarcando como, sob quais condições e para o usufruto de quem, a interação contraditória entre capital versus trabalho configura e reconfigura territórios, compreendidos como todo e qualquer espaço em produção.

O que se pretende dizer é que, não podendo haver separação entre produção (do turismo) e consumo (por turistas) nesses espaços "divorciados", torna-se sem cabimento a menção de que há um "tipo" de relação do "turismo sem o território", quando o que existe é uma série de complexidades (trabalho, turismo, capital, ideologia, bens culturais) de uma totalidade (forma social) e o papel da ideologia na alienação dos indivíduos-turistas deve ser considerado e estudado. Ao mesmo tempo, são exatamente esses grupos atrelados ou não a unidades produtivas de serviços (operadoras, agências, alojamentos) que podem propiciar outras e novas dinâmicas às realidades socioespaciais, fazendo-as reflexos desse consumo e confirmando que a produção determina o consume.

Mas o inverso também é verdadeiro: “a produção medeia o consumo, cujo material cria, consumo sem o qual faltaria-lhe o objeto. Mas o consumo também medeia a produção ao criar para os produtos o sujeito para o qual são produtos" (MARX, 2011, p. 53). Ou seja: não há uma dinâmica do espaço que opera por trás de empreendimentos turísticos (ou um tipo de turismo sem o território), mas existem relações somente possíveis pelos sujeitos em interação, sendo que essas não são necessariamente alcançadas e compreendidas por eles em seus fundamentos no simples contato com tal ambiente social. Conforme será verificado adiante, a ideologia como inversão ou falsa consciência possui apenas (apenas!) um papel em relação a isso.

O fato é que a análise da relação dialética, ou seja, as contradições da unidade ou do todo social e suas determinações (categorias) precisa ser empreendida, caso contrário, a averiguação prende-se a "tipos" específicos ou ideais que se relacionam conforme suas funcionalidades na estrutura idealmente recortada e descolada do pressuposto fundamental - as forças produtivas e o tecido social que as movimentam.

Knafou (1996, p.73) finaliza sua abordagem a respeito do turismo e do território, com a seguinte colocação: “[...] se recusarmos o domínio exclusivo do mercado sobre esta atividade humana [o turismo] que é um importante meio de desabrochamento do indivíduo e se tentarmos colocar um pouco de ordem num fenômeno multiforme, teremos então feito um 


\section{PONDERAÇÕES ACERCA DA IDEOLOGIA NO E DO ESPAÇO TURÍSTICO}

Rodrigo Meira Martoni

pouco de progresso". Tal afirmação ${ }^{10}$, que relega a segundo plano uma categoria que é ontologicamente precedente (o produzir e o reproduzir-se), desata a prática social da categoria valor e situa o planejamento embasado em uma lógica-racional-ideal como ente responsável pela instauração de "um pouco de ordem". Além disso, constitui-se em um posicionamento invertido, o qual, uma vez absorvido para propiciar legitimidade às ações de um poder político, por exemplo, acaba servindo de máscara às reais vinculações e, portanto, limitações desse importante instrumento (do planejamento) pelo e com o chamado "sociometabolismo do capital" (MÉSZÁROS, 2006).

Considerando que as verdades parciais são mais fáceis de serem acessadas, posto que elas condizem com a observação do fato em sua forma mais explícita; além de que os malabarismo teóricos que, com frases chamativas de alto teor subjetivo invertem os papéis (o Estado é quem produz a sociedade civil e não o contrário, os planejadores e promotores territoriais é que dinamizam a sociedade e não o contrário) e podem apresentar exequibilidade pontual (a reforma de uma praça, um projeto de inclusão social via criação de empregos, a restauração de edificações, as oficinas de empreendedorismo para o desenvolvimento com bases locais, a delimitação de um circuito gastronômico ou cultural), eles acabam criando e alimentando a ilusão de que planos e projetos transformados em ações amenizam ou mesmo eliminam certas relações intrínsecas ao modo de produção capitalista, tratando-as de maneira tão natural que acabam não sendo pensadas e compreendidas e, por extensão, deixam de ser discutidas e questionadas.

O sentido prático de que fala Eagleton e do qual a ideologia se vale para tratar situações que são sociais como se fossem inatas aos seres ou naturais (e, incessantemente, tenta dissipar caminhos para análises circunstanciadas), está ligada a blocos de poder e equivale ao que Lefebvre (2008, p.45) chama de "espaço instrumental", [o qual] permite impor uma certa coesão (pela violência) [quando se faz necessário], quanto dissimular as contradições da realidade (sob uma aparente coerência racional e objetiva), [sendo que] os termos 'coesão' e 'coerência' significam regulação buscada, pretendida, projetada, o que não quer dizer obtida". O desdobramento frustrado para o "bem de todos", mas exitoso para o proveito de alguns, se explica pela própria sociedade de classes e, portanto, pela relação capital versus trabalho, fazendo com que mesmo as propostas mais sensíveis e até mesmo conhecedoras de tal relação contraditória não tenham condições de tocar em suas tramas constitutivas e reprodutivas caso não se posicionem em uma condição prática de enfrentamento.

\footnotetext{
10 O autor trata o "mercado" no sentido da economia (receitas, despesas, gráficos, fórmulas) e não da crítica à economia política (como se produz a sociedade capitalista, envolvendo as interações contraditórias a partir do trabalho que promove a variação do valor concretizando o valor a mais). O primeiro somente pode ser revelado e exposto enquanto relação estabelecida historicamente por meio da segunda.
} 


\section{PONDERAÇÕES ACERCA DA IDEOLOGIA NO E DO ESPAÇO TURÍSTICO}

Rodrigo Meira Martoni

E não poderia ser diferente, pois, conforme nos lembra Lefebvre (2008, p.57), "as contradições do espaço não advém de sua forma racional, tal como ela se revela nas matemáticas. Elas advêm do conteúdo prático e social e, especificamente, do conteúdo capitalista". Caso não fosse assim, seria possível verificar a resolução absoluta de contradições e antagonismo via aplicação das alíneas de manuais, como aqueles direcionados ao "turismo responsável" a partir de "políticas locais".

Uma diferença a ser ressaltada é que existem ideólogos que nem sempre sabem a que interesses está submetido e, a maioria, nessa quadra da história, se movem com total clareza de quem os governa. Esses últimos contribuem conscientemente com a formação de uma falsa consciência para o favorecimento das classes dominantes. Frederich Hayek é um exemplo. Tendo suas publicações financiadas pelas instituições mais reacionárias do planeta, sua colocação comentada por Mészáros (2006, p. 197) de que "sem os ricos [...] os pobres que existissem seriam muito mais pobres" busca, por um lado, apontar que os interesses das classes dominantes são direta e indiretamente estendidos a outras classes e, por outro, apagar o fato de que os representantes da riqueza somente têm condições de sê-lo pela produção socializada e pela forma histórica e social de sua apropriação. Nesse sentido, Hayec é um expoente pensador da parcialidade e disseminação de uma perigosa ideologia, pois trabalha em um nível de abstração que é de fácil apreensão pela experiência cotidiana das pessoas.

Mas existem outros situados do lado oposto em relação a personagens da estirpe de Hayec e empenham-se em apontar uma saída para as desigualdades que impedem o desenvolvimento das diferenças humanas. Alguns que se debruçaram no estudo do turismo, como Knafou, servem como exemplo por apresentarem preocupações socioespaciais legítimas, mas invertidas no que se refere às mediações com o ponto de partida ${ }^{11} \mathrm{e}$, consequentemente, em seus resultados práticos.

O que se pretende ao mencionar tais pensadores é ressaltar o que foi anteriormente apontado: a ideologia como falsa consciência ou pensamento atrelado a verdades aparentes não pode ser desconsiderada por um instante sequer em sua operacionalidade ou em sua função social, muito ao contrário, ela possui uma significativa influência na prática produtiva e reprodutiva cotidiana, desencadeando ilusões e concepções de mundo totalmente parciais, seja quando partem de sujeitos conscientes de seus papéis em amplos processos de mistificação da realidade, seja daqueles que desconhecem ou pensam conhecer os condicionalismos socioespaciais vigentes e habilitam a consciência pura como auto-produtora das necessárias mudanças.

${ }^{11}$ A mediação em relação ao ponto de partida refere-se às ideias concebidas e que se autonomizam no processo de abstração, o que não significa a inexistência do ente empírico como referencial de averiguações. Esse será sempre o sinal, tanto para as abstrações desconexas como para aquelas que retornam ao real com possibilidades de explicá-lo, tal como coloca Marx quando aborda o método da economia política na introdução dos Manuscritos de 1857-1858. 


\section{PONDERAÇÕES ACERCA DA IDEOLOGIA NO E DO ESPAÇO TURÍSTICO Rodrigo Meira Martoni}

A inversão e as formas aparentes geralmente associam-se nos espaços tornados turísticos, ajudando, em seus devidos limites, a delimitar a liberdade dos sujeitos no que se refere à apreensão de suas relações com e no conjunto das objetividades humanas (materiais e imateriais): a primeira por carregar a ideia de que os projetos e programas de incentivo à estruturação do turismo podem contribuir com uma sociedade mais justa, preservacionista e inclusiva ao oportunizar empregos e/ou iniciativas diversas; e a segunda, ao tentar evidenciar os atributos socioespaciais fracionados como se fosse a realidade de todo o espaço.

Ambas, compreendidas como resultados de pseudoteorias, pois não têm condições de reproduzir a realidade social no pensamento, acabam tragadas como meios que servem tanto para a legitimação de ações do Estado e da classe dominante (ou frações dessa), à qual tal instituição está intimamente associada, como para o desenvolvimento do turismo a partir de iniciativas localizadas já experimentadas e "acertadas" (como, por exemplo, a Prainha do Canto Verde, em Beberibe-CE).

Por outro lado, as teorias efetivas que assim podem ser caracterizadas ao darem conta da reprodução ideal de um momento da dinâmica socioespacial, acabam sufocadas por tais representações que confundem a teorização da vida prática real (a qual pode orientar os sujeitos sociais) com aquela (pseudo) teorização para a prática operacional (que é pragmática para a produção nessa e dessa forma social e, portanto, não diverge dos ditames do valor-capital).

Conforme expõe Eagleton (1997, p. 79) “as ideias podem ser consideradas ideológicas porque negam suas raízes na vida social [...]; ou podem ser ideológicas exatamente pela razão oposta - por serem expressões diretas de interesses materiais [...]". Tal associação entre formas aparentes e inversões operam naqueles espaços que podem ser adjetivados como turísticos na razão direta da ascensão do trabalho produtivo nos serviços e dos capitais rentistas. Constata-se isso em realidades tal qual a da cidade colonial mineira de Ouro Preto, localidade que conjuga a inversão pelos projetos e programas preservacionistas e a parcialidade pela projeção das formas, ou seja, uma ideologia no espaço para a ilusão coletiva.

\section{A ideologia no espaço: o centro de Ouro Preto-MG como exemplo marcante}

É possível afirmar que tais questões (inversão e parcialidade) concretizaram-se em Ouro Preto com a evolução das visitações e apropriação do patrimônio como algo que, além de possuir uma significação ou um valor de uso para parte dos seus habitantes e viajantes (certamente a alguns daqueles não vinculados aos chamados pacotes turísticos), acaba alcançado como valor para a produção e reprodução do capital associado às rendas diferenciais e de monopólio. Mas é preciso observar mais atentamente tal processo: inicialmente, a categoria patrimônio em sua relação com o valor (e não com o valor de uso ao qual 


\section{PONDERAÇÕES ACERCA DA IDEOLOGIA NO E DO ESPAÇO TURÍSTICO Rodrigo Meira Martoni}

está atrelado o simbolismo ou a significação) não estava desenvolvida devido à quase inexistência de uma dinâmica produtiva no momento da realidade socioespacial em questão, seja via atividades turísticas, seja por transações imobiliárias. Faço referência ao final da década de 1930 quando Manuel Bandeira, ao escrever suas observações no formato de um guia da cidade, coloca que "Ouro Preto é a cidade que não mudou, e nisso reside o seu incomparável encanto". Em seguida, o poeta apresenta o motivo para essa estagnação mantenedora do barroco: “[...] os prédios novos são exceção em Ouro Preto. Ela conservou, mercê de sua pobreza, uma admirável unidade" (BANDEIRA, 2000, p. 34).

Bandeira refere-se ao fato de que a riqueza produzida na então Vila Rica do século XVIII cedeu espaço à pobreza, tanto pela forma como era produzida e distribuída, como pelo declínio da atividade mineradora, ficando os monumentos religiosos, casarios e prédios públicos conservados por sua módica fluidez econômica. Iniciada no início do século XIX e acentuada com a mudança da capital, em 1897, para Belo Horizonte, somente na década de 1950 tal processo muda de curso, primeiramente com a ativação da fábrica de alumínio canadense Alcan (atual Novelis) ${ }^{12}$ e, algum tempo depois, como cidade-sede de uma universidade federal, a qual foi criada em 1969 e que integrou duas antigas escolas, a de Farmácia (de 1836) e a de Minas (de 1876).

As relações redimensionadas com a atuação da empresa e da instituição de ensino, além da constituição de unidades produtivas menores (de bens, mas principalmente de serviços) como suporte à população que, em 1960, retomou o número do momento de mudança da capital (SIMÃO, 2006), acabaram por reconfigurar as adjacências do antigo núcleo urbano descrito por Manuel Bandeira. Bairros estabelecidos conforme as necessidades de reprodução cotidiana dos sujeitos que se dirigiam a Ouro Preto com a intenção de encontrar meios de sobrevivência surgiram com a mais brutal falta de estruturação.

Costa (2011, p.334) observa que a quase totalidade dos morros ocupados e mesmo as áreas um pouco menos acidentadas, como o bairro Saramenha, são caracterizados pela "ausência de planejamento e controle urbanos [...], o que redundou em ocupações e assentamentos precários, de riscos geológicos, além de serem, em sua maioria, áreas com restrito acesso aos serviços urbanos [...]". Contraditoriamente, nos poucos espaços onde a racionalidade do planejamento das formas está estampada, essa acentuou a desigualdade socioespacial conforme o crescimento populacional e ampliação do acesso ao crédito, pois mercado imobiliário e preços os fecham aos pobres, os quais são e tendem a ser confinados nos locais mais inapropriados a uma vida digna.

${ }^{12}$ Desde 2007 pertencente a Aditya Birla Group, com sede em Mumbai, Índia. 


\section{PONDERAÇÕES ACERCA DA IDEOLOGIA NO E DO ESPAÇO TURÍSTICO}

Rodrigo Meira Martoni

À época dos itinerários poéticos de Manuel Bandeira pela Ouro Preto pouco fluída em termos produtivos do patrimônio edificado, servindo este mais como simbolismo ou valor de uso para alguns do que propriamente às relações sociais que fazem de uma coisa valor, o movimento modernista já havia realizado uma viagem às antigas cidades mineiras (em 1924) com o intuito de colocar em voga uma identidade da arte genuinamente nacional, identificada por Mário de Andrade anos antes. Com isso, nasce a noção de "'cidade histórica' [como] uma criação da sociedade moderna do início do século $\mathrm{XX}$, [sendo ela um] produto de uma necessidade de afirmação de 'identidade pelo território', na forja do Estado-nacional" (COSTA, 2011, p.129). Em 1933, Ouro Preto é enquadrada como Monumento Nacional pelo decreto-lei 22.928 e, em 1938, foi inscrita no Livro de Tombo das Belas Artes, um ano após a criação do órgão federal de preservação, atual Instituto do Patrimônio Histórico e Artístico Nacional (IPHAN) (SIMÃO, 2006).

Começava, naquele período das andanças de Manuel Bandeira (sendo ele próprio um modernista incentivador da visibilidade daquele patrimônio até então esquecido com a publicação do seu guia turístico), uma preocupação focada no conjunto urbanístico estabelecido no século XVIII, inicialmente por órgãos federais e estaduais e, posteriormente, pelo poder público local e organismos internacionais como a Organização das Nações Unidas para a Educação, a Ciência e a Cultura (UNESCO), a qual, em 1980, inclui Ouro Preto em sua listagem do patrimônio cultural da humanidade.

$\mathrm{O}$ centro esplêndido impunha-se enquanto os "assentamentos precários" evidenciados por Costa (2011) se corporificavam como resultados não somente das novas dinâmicas das relações sociais produtivas ligadas inicialmente à fábrica de alumínio, mas, também, ao foco das ações do Estado e instituições nacionais e internacionais nesse "centro histórico" ou no conjunto patrimonial com relevante apelo turístico: o desdém com o entorno se gestava paralelamente aos decretos, inscrições, apreciações, histórias e poesias.

Para o turismo e o mercado imobiliário, conforme já mencionado, o valor de uso, simbolismo ou significação é algo secundário em si, sendo que desconsiderar isso é passar ao largo das reais finalidades das relações entre os seres no capitalismo ou dar maior apreço às questões cognitivas (operacionais e ideais) enquanto se desconsidera as ontológicas. Dessa forma, a interação primordial do patrimônio mundial é com a categoria valor, independentemente de o seu valor de uso continuar a atender fantasias, sonhos românticos, boas e más lembranças. Conforme aponta Marx (2008, p. 115):

Consideram-se meros símbolos os caracteres sociais adquiridos pelas coisas ou os caracteres materiais assumidos pelas qualificações sociais do trabalho na base de um determinado 


\section{PONDERAÇÕES ACERCA DA IDEOLOGIA NO E DO ESPAÇO TURÍSTICO Rodrigo Meira Martoni}

modo de produção, e, ao mesmo tempo se sustenta que eles são ficções arbitrárias sancionados pelo consentimento universal. Era esse o modo de proceder típico do iluminismo em voga no século XVIII, para eliminar, pelo menos transitoriamente, a aparência misteriosa das formas então enigmáticas das relações entre os homens, cuja origem não se podia ainda decifrar.

Sabe-se que o ideário iluminista com a célebre expressão liberdade, igualdade e fraternidade ${ }^{13}$ não teve condições de se realizar em termos práticos, pois os movimentos revolucionários resultaram, sobretudo, na transferência dos privilégios de uma classe para outra, podendo a burguesia firmar o seu poder como representante do capital e, portanto, como classe que resguarda as relações sociais que possibilitam a sua existência e expansão. Tal ideário, baseado no "apelo a uma natureza desinteressada, à ciência e à razão, em oposição à religião, à tradição e à autoridade política, simplesmente mascarava os interesses de poder a que essas nobres noções secretamente serviam" (EAGLETON, 1997, p. 66). E isso se estende e se aprofunda nos dias de hoje: há uma ideologia que, ao enquadrar e divulgar a preservação do patrimônio enquanto valor de uso ou puro simbolismo acaba por conformar uma consciência falsa ou invertida, situando as boas ideias associadas ao empenho do Estado, da iniciativa privada e de filantropos como a saída para a resolução de antagonismos e contradições.

Tais discursos e ações preservacionistas, sendo muitos deles com boas intenções e embasados em estudos pormenorizados, desconhecem ou negam as relações sempre e cada vez mais contraditórias das categorias capital, rendas, patrimônio e turismo, bem como os expedientes que geram a magnitude da primeira (a exploração do trabalho) e a sua natureza (as relações humanas mediadas pela mercadoria). Por isso a advertência de Marx (2008, p. 115) quanto ao desvio dos fatos reais quando se considera "meros símbolos os caracteres sociais adquiridos pelas coisas ou os caracteres materiais assumidos pelas qualificações sociais do trabalho na base de um determinado modo de produção".

Sendo assim, aos ideólogos que desconhecem os condicionalismos sociais reais (ou a forma de produção material da vida social), "a ideologia [...] relaciona-se com um vigoroso programa de engenharia social, que irá refazer nosso ambiente social, alterando assim nossas sensações e

\footnotetext{
${ }^{13}$ Mészáros (2007, p.186) nos lembra de que no curso histórico-social as ideias de "'fraternidade' e [...] 'igualdade' tinham de ser totalmente rejeitadas, frequentemente com indisfarçável desprezo, e a 'liberdade' reduzida ao frágil esqueleto do 'direito democrático ao voto'. Essa última, deve-se enfatizar, restringe-se pelo próprio poder da ideologia associada a governos democráticos e até aqueles que se dizem representantes da classe trabalhadora, como o PT no Brasil. Contudo, essa liberdade restrita pode se tornar ainda mais frágil quando as relações socioespaciais comandadas pelo capital se veem ameaçadas: “[...] como a história no século XX demonstra amplamente, mesmo as escassas medidas de igualdade formal são com frequência consideradas um luxo inacessível e anuladas sem cerimônia por práticas políticas corruptas e autoritárias, ou ainda por intervenções ditatoriais realizadas abertamente" (MÉSZÁROS, 2007, p. 186).
} 


\section{PONDERAÇÕES ACERCA DA IDEOLOGIA NO E DO ESPAÇO TURÍSTICO Rodrigo Meira Martoni}

modificando, por conseguinte, nossas ideias" (EAGLETON, 1997, p.67). Dessa falsa consciência aproveitam-se algumas instituições que, por um lado e, nesse caso, visualizam o urbano somente nos limites do núcleo tombado e, por outro, buscam benefícios econômicos diretos e/ou indiretos via preservação e manutenção dos bens patrimoniais. E é justamente da associação dessas ideologias (inversão, formas fenomênicas e de grupos economicamente dominantes) que as obras de restauro e salvaguarda tornam-se realidade, bem como a instalação de mobiliário urbano, os paisagismos, os festivais, os cursos de bem receber e as sessões onerosas de instituições públicas a empresas mineradoras que têm, dentre suas estratégias mercadológicas, a "educação" patrimonial.

Costa (2011) complementa a explicação dessa dinâmica em Ouro Preto: no momento em que a cidade passa a constar na lista da UNESCO no início da década de 1980, as recomendações e conceitos de tal organização são absorvidos por organismos que ele denomina de "arquitetos do mundo" (COSTA, 2011, p.166) tal como o Banco Interamericano de Desenvolvimento (BID) e os Estados Nacionais. Tais “arquitetos" valem-se dos posicionamentos e ações anteriormente mencionados (estudos, propostas, ações educacionais) com o intuito de preservar e atribuir valor para a troca:

[...] simultaneamente à busca da proteção [pela UNESCO e seu
comitê] caminham os agentes diretamente propulsores da
'patrimonialização global', aqui tratados como arquitetos do
mundo [...]. Logo, graças à ciência, à tecnologia e à informação
(que dão nova forma aos territórios e favorecem conexões mais
longínquas que levam ao desenvolvimento das relações
internacionais), além da difusão do conhecimento sobre os
lugares especiais, que objetivam a preservação das
singularidades, o processo de mundialização econômica
subsidiada pelas agências multilaterais se apodera de tais
singularidades (no caso o Patrimônio Mundial) e mesmo de
discursos científicos para se auferir não apenas o lucro, mas a
renda de monopólio nos lugares 'construídos' como especiais
(COSTA, 2011, p. 169).

O trato com os bens patrimoniais tem como referência uma série de recomendações de que são exemplos as cartas, compromissos e recomendações, sendo que as Normas de Quito (1967) em conjunto com a Carta de Veneza (1964) atrelam a conservação à utilidade do bem. As primeiras são mais explicitas em relação às diretrizes sugeridas no que se refere à atribuição não de uma simples finalidade, mas, em última instância, de um finalismo econômico a conjuntos arquitetônicos: observase que o item $\mathrm{V}$ das Normas de Quito pontua sete questões relativas à "valorização econômica dos monumentos", enquanto o VII traz mais sete recomendações acerca dos "monumentos em função do turismo" (IPHAN, 2000, p. 109-115 passim). 


\section{PONDERAÇÕES ACERCA DA IDEOLOGIA NO E DO ESPAÇO TURÍSTICO Rodrigo Meira Martoni}

Costa (2011, p. 151) adverte que, esses documentos atrelados a uma listagem do patrimônio em todo o mundo e a atuação de gestores locais para adaptar os "centros históricos" de acordo com tais normativas, acabam servindo como chancela para "o processo simultâneo, relacional e contraditório de uma 'preservação' para a 'mercantilização' do patrimônio no Brasil [...], necessária à reprodução do capital nas 'cidades históricas' através do turismo".

Um exemplo pontual dessa grande indústria patrimonial afinada com o turismo e os agentes imobiliários (2011) é o Programa Monumenta, do qual Ouro Preto faz parte. Trata-se de uma ação do governo federal que começa a ser gestada em 1995 no contexto do Plano Avança Brasil, sendo o contrato de financiamento com o BID assinado em 1999. Segundo Costa (2011, p.268) do total de recursos para cada município participante (definidos pelo IPHAN), "70\% [são] de aporte federal, aí incluídos os valores referentes ao Contrato de Empréstimo junto ao BID e $30 \%$ de contrapartida municipal ou estadual [...]".

A concretização do programa ocorreu pela associação estratégica entre a falta de direcionamentos de recursos do fundo público para o restauro e preservação de bens patrimoniais e pela disponibilidade de financiamento do BID, segundo a lógica de que o mercado constitui-se como o interventor mais apropriado. Deve-se esclarecer que o interesse do referido agente financiador na viabilidade econômica do patrimônio mundial se acentua com o financiamento para a recuperação do centro histórico de Quito, no Equador, após um terremoto em 1988, uma vez que tal conjunto de obras conferiu ao espaço uma nova dinâmica econômica com a participação do mercado imobiliário e de comerciantes voltados, sobretudo, aos fluxos turísticos (POZZER, 2011).

A partir daí, o BID passa a formular mecanismos de contrapartida para a concessão de financiamento que podem ser encontrados no Monumenta, os quais, em termos gerais, constituem-se na formulação de modelos "de políticas públicas que conciliem a conservação do patrimônio, a dinâmica econômica e os interesses imobiliários" (POZZER, 2011, p. 53). Nesse sentido, o programa opera visando: 1) a preservação patrimonial necessariamente associada a sua utilidade econômica, sendo que a manutenção do conjunto deve passar a ser auto-sustentada por empreendimentos privados; 2) que se efetive a conscientização do "valor histórico" dos bens atrelada e somente possível pelos novos usos; 3 ) que as áreas de intervenção constituam-se em unidades harmônicas e de expressivo impacto visual, fomentando a movimentação de turistas.

Costa (2011, p.269) aponta, ainda, que essa ação integrada buscada pelo programa com investimentos conjuntos (Estado, investidores privados, BID) e focadas no patrimônio e acessos, "se refere mais à atuação de capitalistas e menos à 'integração' popular efetiva [...]", fato que pode ser observado não somente em Ouro Preto, mas nas outras realidades alcançadas pelo BID. 


\section{PONDERAÇÕES ACERCA DA IDEOLOGIA NO E DO ESPAÇO TURÍSTICO Rodrigo Meira Martoni}

É o caso do bairro Pelourinho e "centro histórico" de Salvador, também inscrito como patrimônio mundial pela UNESCO (1981) e que passou por uma verdadeira "limpeza" social chamada de "requalificação" (BARBOSA, 2001, p. 90). Por meio da restauração, inicialmente de cerca de 400 casarões, o intuito era viabilizá-los para o comércio mediante desapropriações seguidas de indenizações que mal possibilitaram o acesso dos então habitantes do Pelourinho a um barraco na periferia de Salvador-BA. Citando uma reportagem do jornal Folha de São Paulo, de agosto de 1994, Barbosa (2001, p. 90) expõe a quem serve o processo de cenarização com a afirmação da arquiteta Adriana Castro, ex-diretora do Instituto do Patrimônio Artístico e Cultural da Bahia. Segundo ela, o objetivo era "transformar um bairro decadente, habitado por desempregados, prostitutas e traficantes, numa região que conjugasse preservação histórica e valor imobiliário".

Entende-se que a palavra revitalização, quando proclamada por órgãos como o IPHAN, o BID e agentes estaduais e municipais do patrimônio, geralmente é sinônimo de realidade socioespacial marcante e livre de conflitos sociais, a qual é um dos resultados do jogo de interações contraditórias que a fazem parecer um ambiente autêntico. A racionalidade para e pela questão econômica traduz-se na irracionalidade para com os sujeitos que se tornam empecilhos ou algo insalubre que deve ser eliminado, não importando a patologia dessa condição. E essa é a forma de promover a circulação de turistas e a produção associada a essa dinâmica.

Pode-se afirmar, com isso, que o discurso e as ações preservacionistas associadas ao desempenho dos "arquitetos do mundo" (COSTA, 2011) invertem o entendimento dos sujeitos e os confinam nos circuitos valorizados como valores (e não como valores de uso de onde provém a substância que, no capitalismo, somente vale enquanto ente intercambiável), a partir de um referencial empírico que trata a história e a cultura como elementos estanques, ou, conforme colocam Marx e Engles (2007, p.65), "limita-se a nos oferecer a história das ideias, desconectada dos fatos e dos desenvolvimentos práticos que lhe servem de base [...]". E essa é a contradição: o turismo histórico-cultural ante a mercadoria "patrimônio" acaba, em termos ideológicos superestruturais ou por uma ideologia no espaço turístico, invertendo e fracionando, podendo ser compreendido como prática que contribui cada vez mais com a alienação reificada na razão direta do desenvolvimento ou evolução de um mercado que firma-se, também, com a beleza dos cenários.

Tal fato em território mundial advêm do que Marx e Engels (2007, p. 87) chamam de "a grande indústria", sendo que essa pode ser metamorfoseada aqui pelo turismo e pela patrimonialização: "[ela], por meio da concorrência universal, obrigou todos os indivíduos ao retesamento extremo de suas energias. Destruiu, onde foi possível, a ideologia, a religião, a moral etc. e, onde logrou fazê-lo, transformou-as em uma mentira palpável". Os atributos socioespaciais que ela não almejou 


\section{PONDERAÇÕES ACERCA DA IDEOLOGIA NO E DO ESPAÇO TURÍSTICO}

Rodrigo Meira Martoni

incluir ou, ao menos, não alcançou a partir de algumas atividades como o turismo, a significação dos sujeitos ligada a categoria valor de uso, contraditoriamente, pode ter ficado somente na memória.

Desligada ou desarticulada a relação valor de valor de uso e, daí, valorcapital e rendas, as belas edificações do século XIX que margeiam a estrada de ferro da Graciosa na Serra do Mar do Paraná ruíram; e o mesmo processo pode ser observado com o conjunto arquitetônico da Central do Brasil entre os estados de Minas Gerais e Rio de Janeiro e muitos outros casos, o que demonstra que a significação (subjetiva) não pode fazer de um valor de uso, valor. Este fato pode comprometer e compromete uma diversidade de objetividades humanas extremamente marcantes em relação a um tempo histórico e/ou a configuração de um espaço, enquanto requalifica outras.

A "totalidade urbana" de Ouro Preto como "totalidade-mundo" de que fala Costa (2011) significa a preocupação evidente com o patrimônio em escala local sob imperativos de instituições representativas do capital em escala mundial, preocupação essa que serve como mediação entre o turismo e a produção de valor e/ou obtenção de rendas. $\mathrm{O}$ segundo propósito não aparece em uma primeira averiguação ou fica difuso nessa ideologia invertida dos grandes projetos e das formas, mas é ele o ente primordial. Com isso, aos responsáveis pela existência do valor a mais (a classe trabalhadora) inseridos na dinâmica do patrimônio para e pelo turismo, o próprio posicionamento deles na estrutura de classe dos circuitos produtivos os relega aos morros com as formas de habitação mais precárias que, se não poderiam aparecer no guia do poeta na década de 1930 por questões empiricamente impossíveis de se registrar, hoje não aparecem devido aos holofotes no espetáculo patrimonial ${ }^{14}$.

Para aqueles que têm condições de controlar tal produção e devem se empenhar na geração de excedentes como principio básico de acumulação, competitividade e domínio de mercado, fica o "centro histórico" como limite geográfico em que as leis operam visando o cuidado e a proliferação dos negócios, incluindo a história e a cultura como mercadorias situadas nos trajetos turísticos dos mais variados (gastronômico, religioso, cemiterial). Aos turistas ficam os encantos arquitetônicos e o esvaziamento das efetivas relações de produção e consumo em um "autêntico" espaço do século XVIII.

\section{A Ideologia Como Posicionamento de Classe}

Em "A ideologia alemã", Marx e Engels apresentam o que se pode considerar como a segunda noção de ideologia: trata-se do conjunto de

${ }^{14}$ Como exemplo é possível citar o Guia Quatro Rodas publicado pela Editora Abril. 
ideias de classes sociais postos para explicar, fundamentar, defender e justificar suas posições e interesses. Por um lado, e tendo em vista o empenho para se resguardar as relações que fazem de uma classe a classe dominante, Marx e Engels (2007, p. 71) explicam que "as ideias dominantes não são outra coisa a não ser a expressão ideal das relações materiais dominantes, as mesmas relações materiais dominantes concebidas como ideias". No que se refere a essa classe e a teia de interações políticas e econômicas que estão perpassadas por suas conveniências, há de se considerar a atuação das frações de classe, as quais apresentam ou podem apresentar discordâncias e indisposições acerca das ideias gerais em certos momentos, mas essas tendem a arrefecer ou a desaparecer "tão logo surja qualquer colisão prática suscetível de pôr em perigo a classe em si" (MARX; ENGELS, 2007, p. 72).

Por outro lado, as ideias que procuram ser esclarecedoras e, ao mesmo tempo, desmistificadoras, conformam uma ideologia que lida com: 1) o combate às expressões da ideologia dominante, o que inclui as verdades parciais e as inversões advindas dos "ideólogos conceptivos ativos da referida classe [...]" (MARX; ENGELS, 2007, p.71); 2) o devido posicionamento de tais ideais em uma estrutura de classes e em uma processualidade histórica e social, uma vez que, sendo as ideias dominantes aquelas que servem a um modo de dominação com especificidades próprias (o capitalismo), elas são postas para que sejam absorvidas por aqueles indivíduos que pertencem a outras classes como um ideal a ser alcançado, o qual poderia ser plenamente realizado pelo esforço pessoal ou pela pura subjetividade apoiada em si.

Tal fato, levado a cabo por instrumentos diversos como os meios de comunicação de massa e a quase totalidade da educação formal, colabora para que os sujeitos não tenham consciência da classe à qual pertencem, mas os fazem portadores de um sistema de ideias relacionado à classe que almejam pertencer ${ }^{15}$, fomentando a competitividade (para o mercado e não para o desenvolvimento social) como fim último dos indivíduos e de suas objetivações; 3) a reinversão das ideias invertidas que até podem ser combativas frente às ideias dominantes mas, ao se prenderem a projetos pontuais e descolados da forma de produção material e imaterial da sociedade, acabam até mesmo servindo aos interesses das classes que detêm o poder econômico por não tocarem nos aspectos gerais e fundamentais dessa dominação.

É preciso esclarecer que, tal como a classe dominante, as outras classes sociais são compostas por estratificações, como a "classe média superior" e a "classe média inferior" (HOBSBAWM, 2010, p. 19) e, daí, existem diferentes e conflitantes posicionamentos políticos e ideológicos a

15 Tal ideologia esconde estrategicamente o fato de que para o capital se perpetuar é necessária a manutenção do trabalhador como trabalhador, ou seja, a apropriação privada e cada vez mais significativa da produção socializada não pode ser abalada. 


\section{PONDERAÇÕES ACERCA DA IDEOLOGIA NO E DO ESPAÇO TURÍSTICO \\ Rodrigo Meira Martoni}

depender de sua condição e da sua consciência em relação a ela própria. Pode-se considerar que as diversas ideologias estabelecem vínculos mais ou menos aproximativos com as ideologias mais relevantes em termos de poder daqueles que, ou representam o trabalho, ou são representantes do capital; questões essas que acabam evidenciadas e potencializadas naqueles momentos da sociedade em que se intensificam os conflitos e as crises geradas pelas contradições entrelaçadas às tentativas constantes e sempre renovadas de expansão do capital, o que inclui: a minimização do trabalho necessário e a expansão do excedente, a eliminação do trabalho vivo, a necessidade de realização cada vez mais ampliada dos produtos e dos serviços e todos os processos daí decorrentes.

Marx e Engels (1997, p. 97) apontam que os dois entes constitutivos da dinâmica socioespacial (as relações sociais de produção e as forças produtivas) em seu movimento contraditório levado a cabo pelos pores teleológicos frente às causalidades, geraram uma classe "que está condenada a suportar todas as cargas da sociedade sem gozar de suas vantagens [sendo isso o pressuposto fundamental para o nascimento de] uma consciência que, naturalmente, pode chegar a se formar também entre as outras classes, se algumas delas contemplar a posição que aquela se acha colocada".

Mas é preciso ponderar quanto a isso, pois em algumas situações da estrutura socioprodutiva e segundo questões que não necessariamente excluem uma e outra, as classes sociais e suas estratificações podem: 1) absorver os ideais dos movimentos contestatórios em relação às ideias e encaminhamentos das classes dominantes e promover movimentações desde a raiz; 2) fazer da concepção ideológica dominante a sua própria percepção de mundo vislumbrando uma situação individual futura; 3) atuar como ente neutro que, por sua própria neutralidade, acaba contribuindo ou revigorando uma determinada estrutura de poder e a sua ideologia; 4) defender posicionamentos que se traduzem em uma ideologia sem bases concretas do ponto de vista contestatório real e, portanto, é impotente em termos práticos para contribuir com transformações qualitativas; 5) se mover segundo uma ideologia da qual não conhece os fundamentos e defender pontos de vista que não conferem com as configurações de sua classe.

Se, conforme aponta Ianni (2004, p. 308), "as mais diferentes correntes ideológicas [tais como] o africanismo [...], o ecologismo [...], o neoliberalismo [...], o nazi-fascismo [...] e o socialismo são ideologias mais ou menos abrangentes, umas vigorosas, outras inconsistentes", o fato a ser enfatizado é que o "aspecto prático e ativo da consciência de classe, sua essência verdadeira, só pode se tonar visível em sua forma autêntica quando o processo histórico exige imperiosamente a sua entrada em vigor, quando uma crise aguda da economia a leva à ação" (LUKÁCS, 2012, p.127). Então, quando se fala em classes sociais, contempla-se o posicionamento dos sujeitos na estrutura produtiva (como representantes, 
produtores ou marginalizados do processo de produção e reprodução do capital) e não conforme as suas possibilidades de consumo e/ou categorias profissionais.

Por isso e considerando tais momentos críticos citados por Lukács (os quais o próprio capitalismo ainda teve condições de contornar as custas de muito suor, sangue, pão e circo), Marx (2010, p. 79) relata nos Manuscritos de Paris "que no fim a diferença entre capitalista e o rentista fundiário desaparece, assim como entre o agricultor e o trabalhador em manufatura, e que, no final das contas, toda a sociedade tem de decompor-se nas duas classes dos proprietários e dos trabalhadores sem propriedade". Tal exame acerca das classes sociais deve abarcar, portanto, tanto a efetiva posição dos sujeitos no processo produtivo e as desigualdades socioespaciais daí advindas, como questões relacionadas à generidade humana no que se refere a etnia, sexo e expressão cultural ${ }^{16}$.

Convém mencionar que a luta de classes não ocorre somente com o embate de ideias ou mesmo o conflito levado às últimas consequências, mas está embutida, por exemplo, na formulação de um contrato de trabalho respaldado juridicamente de forma a resguardar os interesses da uma classe, na fragmentação planejada de um espaço para o trânsito e/ou permanência de turistas, nos conflitos para a criação de uma unidade de conservação, na produção social do conhecimento em universidades, entre outros. O que se pretende enfatizar é que há uma ou mais ideologias no espaço turístico, sendo que, em termos gerais, existe uma relativa a um bloco dominante a depender do desenvolvimento da categoria valor com e no conjunto das atividades características do turismo (ACT's), o qual, por sua vez, poderá gestar, despertar ou enfrentar uma contestatória que se posiciona conforme certos momentos críticos e de acordo com as interações das categorias trabalho, capital, políticas públicas e consciência de classe.

Portanto, não se pode negar o papel das ideologias nos espaços alcançados pelo turismo. O receituário da Revista Exame para o Brasil melhorar os índices de circulação e estadia de turistas estrangeiros,

16 Em relação à discussão entre classe e diversidade de gênero (cor, etnia, orientação sexual), as lutas fragmentadas ou dissociadas da concepção de classe social podem cooperar com os ideias e ações das classes dominantes ao renegarem a concepção classista. Por outro lado, a integração de propósitos discutidos a partir da luta pela liberdade tem possibilidades de denunciar e desmistificar a ideologia dominante. Silva (2011, p. 56) esclarece a questão: “do ângulo da análise e da luta em torno do reconhecimento da liberdade como valor ético central e das diferenças decorrentes da diversidade de gênero e sexual, sua vinculação à perspectiva classista permitiria o ataque simultâneo de todas as opressões, o que aponta para a radicalização da tomada de consciência da totalidade do processo de alienação e a articulação de todos os sujeitos sociais que resistem e lutam contra os processos de dominação-exploração, negando-se e ultrapassando-se abordagens fragmentárias". Nesse sentido, se após a abolição da escravatura no Brasil os negros foram deixados à própria sorte e a discriminação racial é um vestígio marcante da subordinação imposta de uma raça sobre outra, o combate ao racismo passa pelo questionamento de uma estrutura social que fez dos escravos e da quase totalidade de suas gerações posteriores um grupo subordinado enquanto classe. Mas é preciso considerar que a discussão em torno dessa questão não é fácil, pois a ideologia dominante trata a liberdade como algo parcial quando desarticula estrategicamente o gênero da classe social e se apresenta como defensora de alguns ideais de grupos específicos como se os debates e propostas em torno somente do gênero representassem a verdadeira emancipação e libertação. Verifica-se isso, por exemplo, em novelas e propagandas ao se tratar de questões raciais descoladas da classe social. 


\section{PONDERAÇÕES ACERCA DA IDEOLOGIA NO E DO ESPAÇO TURÍSTICO}

Rodrigo Meira Martoni

elaborado a partir de "bons exemplos" de países e localidades, é emblemático: segundo matéria de Caixeta (2004, p.22-30 passim), a África do Sul traz como "lição para o Brasil" o fato de as "autoridades locais [evitarem] o contato do estrangeiro com a dura realidade local"; já a Austrália seria um bom exemplo para a gestão, pois "a administração do turismo não está entregue aos políticos, [sendo] gerida de forma empresarial, como deve ser". Cingapura integra a lista devido à ação articulada de empresários, pois esses "lançaram uma campanha de marketing internacional agressiva [...]", enquanto no México, "sem imposições governamentais, autoridades e iniciativa privada desenvolvem parcerias eficientes para incentivar o turismo". Tais "lições" refletem o modo de ser da classe dominante, o qual pode e deve ser explicado por outra ideologia que, diferentemente, considera as interações contraditórias advindas da desigual divisão social e espacial dos resultados materiais e imateriais derivados da produção.

Muito embora não seja possível deixar de considerar que ao espaço que se quer turístico o ar de liberdade e de festividade, comentado por Lefebvre (2008), é uma das questões principais a serem incorporadas, alguns podem argumentar que existem duras realidades que acabam servindo como atributos a serviço de uma ideologia contestatória que se apropria do turismo como um instrumento, como seria o caso, por exemplo, das visitas às townships ${ }^{17}$ na República da África do Sul. Não deixando de ser uma forma de expor a ideologia do Apartheid que teve vigência legal por quase quarenta anos naquele país, uma vez absorvido como mercadoria por agências receptivas, o turismo não deixa de ser uma forma de alienação, posto que, enquanto empenha-se em envolver especificidades socioespaciais como valores e quanto mais esses conformam uma dinâmica produtiva, mais se desfaz a relação entre história, cultura, política, patrimônio e suas fundamentações sociais reais, as quais continuam a operar de outras e renovadas formas.

O fato é que a absorção dessas realidades como mercadorias reifica ou coisifica as relações humanas, seja pela inserção de situações onde o componente ideológico contestatório de certas condições adquire posição secundária diante da necessidade de venda de momentos a serem vivenciados por algumas horas ou dias; seja com a criação da falsa noção de que a filantropia do turista-social pode contribuir com mutações socioeconômicas e incitar a minimização de mazelas socioespaciais (posto que o sujeito-turista é um mero espectador e continuará sendo enquanto for "turista"). Mas tal reificação está atrelada, principalmente, pela aceitação de "nichos", nos dizeres de Coriolano e Almeida (2007), a serem introduzidos como entes comercializáveis não importando que eles

17 Trata-se dos espaços separados para a habitação daqueles trabalhadores que não eram brancos, geralmente situados nas periferias de vilas e cidades. 


\section{PONDERAÇÕES ACERCA DA IDEOLOGIA NO E DO ESPAÇO TURÍSTICO Rodrigo Meira Martoni}

retratem a miserabilidade e toda a forma de vida que é eticamente inaceitável e, por si mesmos - devido ao tempo da visita ou do trabalho voluntário - não forneçam os elementos necessários a se questionar os seus alicerces ou suas raízes sociais.

Trata-se, no fim das contas, de uma ideologia contestatória que presta serviço à ideologia dominante quando a mercadoria passa a mediar tais vivências. Tal exemplificação introduz o assunto acerca da terceira noção de ideologia, mas essa segunda, sintetizada por Ellul (2012, p. 260) como sendo "des théories élaborées de façon consciente par des hommes ou des groupes pour justifier leur situation"18, não pode ser perdida de vista, assim como a primeira.

\section{A Ideologia do Espaço ou Componente que Emana da Prática Produtiva do Valor-capital}

Por fim, a terceira concepção contempla as outras duas, mas não somente isso. Se há uma imbricação delas como é possível verificar, deve-se reputar a primazia ontológica dessa última conforme será verificado, o que não significa atribuir menos importância à ideologia como inversão, parcialidade e conjunto de ideias mistificadoras e desmistificadoras associadas a grupos sociais e blocos de poder. Se analisada a sequência de elaboração acerca da crítica ao idealismo e ao materialismo mecânico efetivada por Marx e Engels em "A ideologia alemã", ou mesmo algumas questões que foram anteriormente mencionadas - como a tendência de formação de uma consciência de classe em certos momentos e os inevitáveis embates a ela relacionados - chega-se a uma questão central: apontar a ideologia como um conjunto de ideias responsáveis pela manutenção de relações convenientes a uma classe ou, contrariamente, a possibilidade de superação de tais interações por ideias de enfrentamento, seria sobremaneira idealista.

Em relação à obra "A ideologia alemã", convém evidenciar uma questão: nela, verifica-se que Marx e Engels explicam a concepção materialista da história. Uma parte é intitulada "a ideologia em geral, e a alemã em particular", sendo essa composta por dois sub-itens, um denominado "História" e o outro "Sobre a produção da consciência", sendo que, de uma maneira geral, a abordagem trata do processo de formação da consciência atrelado à evolução das relações sociais com o fim de esclarecer os limites do idealismo e delimitar o alcance daquele materialismo que visualiza o ser humano como um "'objeto sensível' e não como 'atividade sensível' [ou seja], sem conceber os homens dentro de sua conexão social dada" (MARX; ENGELS, 2007, p. 69).

Muito embora a ênfase dos autores recaia sobre a pura subjetividade, eles evidenciam que a consciência e, portanto, as ideologias, não

18 "As teorias elaboradas de forma consciente por homens ou grupos a fim de justificar sua situação". 


\section{PONDERAÇÕES ACERCA DA IDEOLOGIA NO E DO ESPAÇO TURÍSTICO Rodrigo Meira Martoni}

determinam a vida prática real, mas o contrário é verdadeiro. Para que a palavra determinação não adquira significado de fatalismo, Marx e Engels (2007, p.70) explicam que o termo significa, dentre outras coisas, "gérmen" ou "influência ativa que a história anterior exerce sobre a que vem depois dela", demonstrando que se a história é feita pelos grupos humanos, ela também somente pode ser alterada pelas condições estabelecidas, as quais, ao mesmo tempo, são absorvidas pelos sujeitos sociais.

Tal colocação é essencial para demonstrar que há uma ideologia dos e não somente nos espaços alcançados pelo turismo: quando Marx e Engels defendem que "a classe que exerce o poder 'objetal' dominante na sociedade é, ao mesmo tempo, [aquela que exerce o] poder 'espiritual' dominante", eles fazem referência a tal "poder objetal" como a "expressão ideal das relações materiais dominantes, as mesmas relações materiais dominantes concebidas como ideias [...]". O que se deve reter aqui é o fato de que se não houvesse relações materiais dominantes, tão pouco haveria ideias ou um conjunto de instituições de respaldo a elas, afinal, são as relações materiais dominantes que acabam formatadas como ideias e não o contrário. Nesse mesmo sentido, "[...] as formas valor, capital e mercadoria transbordam, necessariamente, em forma política estatal e forma jurídica" (MASCARO, 2013, p. 23).

Eagleton (1997, p. 84) entende que, em "A ideologia alemã", Marx e Engels tratam a ideologia como uma "especulação idealista", enquanto n'O Capital, Marx a situa "nas práticas materiais da sociedade" ao desenvolver sua análise sobre o caráter fetichista da mercadoria. No entanto, compreende-se que, nessa obra de 1845-46 (mas publicada somente em 1932), Marx e Engels já apontam o poder da ideologia na vida social permeada e fluída pela mercadoria. Por isso, os autores colocam que "a eliminação [das] noções [idealistas e/ou materialistas mecânicas] da consciência dos homens, é obra das circunstâncias e não das deduções teóricas" (MARX; ENGELS, 2007, p. 64) ou de ideologias. Tais circunstâncias são as condições de vida que precisam ser transformadas, sendo que o próprio conhecimento delas como pressuposto para a mudança passa pelo acirramento de tais condições:

São [as] condições de vida, com as quais as diferentes gerações se encontram ao nascer, que decidem, também, se as transformações revolucionárias que se repetem periodicamente na história serão ou não suficientemente fortes para derrubar a base de tudo aquilo que existe; e se não estão disponíveis estes elementos materiais de uma transformação revolucionaria total [...] em nada contribuirá para fazer mudar a marcha 'prática' das coisas o fato de que a ideia desta transformação revolucionária já tenha sido proclamada centenas de vezes, conforme aliás demonstra a história do comunismo (MARX, ENGELS, 2007, p. $62)$. 


\section{PONDERAÇÕES ACERCA DA IDEOLOGIA NO E DO ESPAÇO TURÍSTICO Rodrigo Meira Martoni}

A segunda parte de "A ideologia alemã", intitulada "A base real da ideologia", contempla as relações sociais que geravam um "capital naturalprimitivo" até aquele que advém da "grande indústria", sendo esse último somente possível com a ascensão do mercado mundial e da forma de produção e concorrência capitalista nessa mesma escala, muito embora com maneiras de penetração e desdobramentos socioespaciais diferenciados. Mas é das diferentes formas de propriedade que culmina na "propriedade privada pura", a qual "já se despojou de todo aspecto de essência comunitária e já eliminou toda a influência do Estado sobre o desenvolvimento da propriedade" (MARX; ENGELS, 2007, p .89) e da organização do trabalho vinculada a ela, que surge e adéqua-se o Estado moderno, o direito e a propaganda dos atrativos turísticos de um país, por exemplo. Tais entes que ajudam na manutenção da sociedade civil serão metamorfoseados em função das relações estabelecidas para a produção de mercadorias.

Conforme mencionado, a ideologia que combate e é combatida pela ideologia dominante e/ou por ideologias representativas de grupos meramente reformistas que buscam uma coesão sem se aterem à base produtiva dinamizada pela relação capital versus trabalho, todas elas, são essenciais no que se refere à consciência e à inconsciência de classe. Ou seja, há de se considerar as ideologias e as condições que alicerçam a sociedade em um dado momento, averiguando o papel tanto daquelas postas para confirmar e resguardar o capital, como daquelas que expõem suas implicações em relação aos sujeitos que devem fazer de suas vidas momentos voltados para o trabalho abstrato e não do trabalho algo para que se possa viver.

Mas a ideologia enquanto poder superestrutural carece sempre de algo essencial, entendido não como a ligação mecânica entre base e superestrutura, mas as "correspondentes relações" em uma determinada forma social, tal como coloca Marx (2011, p.59) na introdução dos Manuscritos de 1857-58 referindo-se a essa dialética como "[...] uma iluminação universal em que todas as demais cores estão imersas e que as modifica em sua particularidade [ou como] um éter particular que determina o peso específico de toda existência que nele se manifesta". Por isso, Marx e Engels (2007, p.102) declaram que "a transformação dos poderes pessoais (relações) em objetais através da divisão do trabalho [por e para o valor a mais] não pode ser supra-sumida ao se arrancar da própria cabeça a noção universal sobre elas [como um "tipo do turismo com o território" via planejamento como quer Kanfou], mas sim fazendo com que os indivíduos voltem a subsumir a seu mando estes poderes objetais [...]".

Não é por outro motivo que Eagleton (1997, p.43) denuncia a existência de um "idealismo de esquerda", o qual "exagera a importância da cultura e da ideologia na manutenção do poder político". Com isso, pretende-se enfatizar que as tentativas sempre renovadas de se manter um mínimo de nexo social dependem da base produtiva e, também, das possibilidades de 
acesso a elementos materiais e imateriais que mantenham os "novos proletários"19 (ABDELNOUR, 2012) em uma situação de certo convívio pacífico ante às desigualdades inerentes à forma social capitalista e às quais estão submetidos enquanto classe. As políticas de bem estar social nos poucos países em que o capital abriu certas concessões estratégicas servem como exemplo da relação firmada a partir dos movimentos da base produtiva, demonstrando que "[...] um telespectador dopado não tardará em participar de um piquete se o seu salário estiver ameaçado, ou em tornar-se politicamente ativo se o governo decidir [...] passar uma rodovia em seu quintal" (EAGLETON, 1997, p. 48).

Mas, o que seria o fetiche da mercadoria como ideologia que ludibria os seres sociais em suas reais condições e a partir deles mesmos? E como o poder das coisas pode superar o poder dos sujeitos sociais? É n'O Capital que Marx irá empreender o detalhamento do fetichismo, demonstrando que a ideologia "não é mais primariamente uma questão de consciência, mas está ancorada nas operações econômicas cotidianas do sistema capitalista" (EAGLETON, 1997, p. 83). E essa é a terceira noção de ideologia assim colocada por Ellul (2012, p. 258): “[...] la production des idées, la représentation du monde extérieur dans un corps social, ne sont pas produites par un mécanisme abstrait ou intellectuel, mais sont liées à l'activité pratique $[\ldots]^{\prime 20}$.

Uma reflexão a respeito da ideologia do espaço tornado turístico e, portanto, enquanto componente da atividade econômica-prática, precisa começar tendo por base referencial a categoria alienação, sobre a qual se fez alusão na exemplificação do turismo nas townships: nos Manuscritos de Paris, Marx relata que "a economia nacional" não explica de onde provém a propriedade privada tratando-a como uma forma natural que sempre regulou as relações humanas. Já sabemos que tal forma de propriedade é um componente resultante do domínio do trabalho por um terceiro, ou seja, uma relação entre sujeitos que, não gerando de imediato essa forma tal como se conhece hoje, consiste em uma prática viável desde que exista a produção de excedentes e que a exploração de um indivíduo em relação a outro se amplie em função deles. Portanto, a propriedade privada tem seu gérmen na apropriação dos resultados do trabalho, sendo "ela a expressão mais crassa da submissão do individuo à divisão [classista] do trabalho, a

19 Conforme esclarece Abdelnour (2012), "les nouveux prolétaires" não se restringem mais aos assalariados principalmente da indústria que, a depender do país até a segunda metade da década de 1970, contavam com mais políticas de bem estar social. Os novos proletários continuam sendo os agentes que dependem da venda de suas capacidades laborativas como único meio de sobrevivência, mas "dont l'emploi et les protections qui l'accompagnent sont discontinus et incertains [...]" (ABDELNOUR, 2012, p.121). Antunes (2009, p.103) detalha que tais grupos ou "a classe-que-vive-do-trabalho" inclui os assalariados, os trabalhadores da economia informal, os contratados por meio período, os terceirizados, os trabalhadores precarizados dos setores primário, secundário e terciário e, também, os desempregados. Desses, estão excluídos os proprietários e gestores do capital, bem como aqueles que, "de posse de um capital acumulado, vivem da especulação e dos juros".

20 "[...] a produção das ideias, a representação do mundo exterior em um corpo social, não são produzidos por um mecanismo abstrato ou intelectual, mas são ligadas à atividade prática [...]". 


\section{PONDERAÇÕES ACERCA DA IDEOLOGIA NO E DO ESPAÇO TURÍSTICO Rodrigo Meira Martoni}

uma determinada atividade que lhe é imposta [...]" (MARX; ENGELS, 2007, p. 76).

Mas há diferenças substanciais das intenções e, portanto, dos processos sócio-históricos em que um sujeito ou grupo subjuga o outro, tal como o trabalho escravo na Grécia antiga, o qual, diferentemente da economia no capitalismo, tinha como finalidade o tempo livre dos cidadãos e não o lucro. Deve-se considerar, também, que as variadas formas de propriedade (comunal, feudal) coexistiram e culminaram em escala ampliada na forma privada somente com o alargamento da troca e da divisão classista do trabalho. Mas, importa retomar aqui, que o domínio da atividade laborativa ou do que é material e/ou imaterialmente objetivado, faz do elemento resultante algo estranho ao próprio trabalhador ao não lhe pertencer, sendo que esse estranhamento alcança e envolve as relações sociais que posicionam os sujeitos-produtores perante aqueles que usufruem dos resultados dessa produção. O trabalho empreendido para a fruição de outros e, portanto, que não está posto em função do desenvolvimento humano, torna-se somente um "meio [...] da existência individual" (MARX, 2010, p. 85) e não um fim em conformidade com as necessidades e possibilidades de desfrute coletivo, ou é meramente um fim para o objeto. Resulta disso "o estranhamento do homem pelo próprio homem" (MARX, 2010, p. 86).

Esse estranhamento em relação aos processos, produtos e relações humanas pode ser compreendido como alienação, ou, conforme esclarece Netto (1981, p.74), essa "desenvolve-se quando os agentes sociais particulares não conseguem discernir e reconhecer nas formas sociais o conteúdo e o efeito de sua ação e intervenção; assim, aquelas formas e [...] a sua própria motivação à ação aparecem-lhes como alheias e estranhas". Sujeitos alienados são, portanto, indivíduos que não compreendem os alicerces ou as raízes sócio-históricas que determinam o seu papel na sociedade, bem como se movem a partir de referenciais fenomênicos ou sensíveis ao toque.

Netto (1981, p. 75) salienta que a alienação de que Marx trata nos Manuscritos de Paris "tem todas as possibilidades de se afirmar e desenvolver sem colar-se ou cristalizar-se em coisas", pois as mercadorias, anteriormente à inscrição do capitalismo como "história universal" (MARX; ENGELS, 2007, p. 87), não embasavam as relações entre os seres, ou seja, a quase inexistência da diferenciação entre o sujeito-produtor e sua vida pessoal ligada a tradições e costumes pela forma como produziam e comercializavam, ainda não propiciava condições para essa separação. $\mathrm{Na}$ alta e em parte da baixa Idade Média, por exemplo, os trabalhadores estavam submetidos a relações de obediência e subordinação frente a um poder atribuído por Deus à nobres e clérigos, e mesmo aos poderes naturais, sendo que "as relações sociais entre as pessoas na realização de seus trabalhos [revelavam-se] como suas próprias relações pessoais, não se dissimulando em relações entre coisas, entre os produtos do trabalho" 


\section{PONDERAÇÕES ACERCA DA IDEOLOGIA NO E DO ESPAÇO TURÍSTICO Rodrigo Meira Martoni}

(MARX, 2008, p. 99). Mas, havendo domínio ou subordinação, havia alienação.

Já o capitalismo avança "como a [forma] mais pronunciadamente social do desenvolvimento das sociedades de classes [...]" (LUKÁCS, 2010, p. 116), no sentido de que as relações fundamentais entre os sujeitos não deixam de ser interações laborativas em prol de outros, mas são movidas agora pela troca ou estão subordinadas ao poder das coisas, momento em que o conhecimento científico passa a revelar as manifestações e dinâmicas da natureza ou aqueles poderes ocultos que nem por isso deixam de habitar e se manifestar na mente dos sujeitos. $O$ fato a ser ressaltado é que esse processo efetiva o rompimento dos vínculos que uniam as individualidades laborativas com as pessoais determinadas pelo nascimento, as quais impediam que um servo se tornasse nobre ou um nobre decaísse à condição de servo. Conforme salienta Marx (2011, p. 411), “a apropriação da 'vontade' alheia é pressuposto da relação de dominação": se, no passado, a dominação era pessoal entre, por exemplo, o senhor e o servo, no capitalismo ela é objetal, ou seja, os sujeitos perante o valor. Dada essa materialidade prática, estão postas todas as condições para que a alienação se acentue, sendo que Marx irá especificá-la no capitalismo como o "fetiche da mercadoria", sendo essa um ente que se situa na base, ou seja, é inerente à produção de mercadorias.

Nos Manuscritos de Paris, Marx "não agarra a especificidade dos processos que se desenrolam na sociedade burguesa constituída e [portanto] não distingue 'reificação' [...] de alienação 'tout court', não discrimina uma espécie do gênero" (NETTO, 1981, p.75). É somente com as análises posteriores acerca da constituição dos sujeitos sociais em conformidade com a organização do trabalho no modo de produção capitalista, bem como pela explicitação das gritantes diferenças dessa forma social em relação às passadas, que Marx terá condições de explicar tal "espécie" de alienação ou o fetichismo que se traduz em relações reificadas. Algumas questões que podem ser percebidas e sentidas no dia a dia por afetar a todos (mas nem por isso são compreendidas em suas operacionalidades reais), precisam ser destacadas ao se focar o "fetiche da mercadoria", o que envolve: 1) o poder dos produtos sobre os produtores; e 2) o fato de que a forma social vigente advém de um processo históricosocial e, portanto, não é algo natural.

Iniciando pela última apontamos que, para o capitalismo se firmar, não bastava a circulação de mercadorias e de dinheiro, mas era imperativo que existisse o trabalhador livre e desprovido dos meios de produção, sendo esse sujeito mantido por si a partir de uma relação de troca desproporcional entre o que produz e o que ganha. Os resultados do seu trabalho são os meios para a sua reprodução obviamente, mas o acesso a eles somente é possível por meio da compra. Se já havia um capital primitivo advindo das atividades mercantis e usurárias, essas se tornam o pressuposto para o capital emergir com todas as suas forças a partir do 


\section{PONDERAÇÕES ACERCA DA IDEOLOGIA NO E DO ESPAÇO TURÍSTICO}

Rodrigo Meira Martoni

trabalhador livre e da propriedade privada, ou seja, é dessa relação social que se conforma o capitalismo:

Se observarmos o dinheiro, verificaremos que pressupõe certo estágio da troca de mercadorias [...]. Com o capital é diferente. Suas condições históricas de existência não se concretizam ainda por haver circulação de mercadorias e de dinheiro. Só aparece o capital quando o possuidor de meios de produção e de subsistência encontra o trabalhador livre no mercado vendendo sua força de trabalho, e esta única condição histórica determina um período da História da humanidade. O capital anuncia, desde o inicio, uma nova época no processo de produção social (MARX, 2008, p. 200).

Importa salientar aqui que tais relações sociais são recentes, tal como pode ser verificado na obra de Hobsbawn (2010) intitulada "A era das revoluções", a qual cobre o período que vai de 1789 a 1848. Convêm somente alguns detalhamentos: muito embora a agitação de alguns mercados no século XVIII fosse significativa e a acumulação por espoliação já tinha dado os seus frutos para os países europeus de vanguarda, sobretudo a Inglaterra, é nesse momento da sociedade que o capital gerado na atividade laborativa começava a operar com a revolução industrial e com o fenômeno da urbanização. Por meio de um pouco de estudo de história permeada e somente possível de se constituir enquanto história pelas relações sociais de produção ou aquelas bases necessárias para que os sujeitos possam viver, torna-se claro que o capitalismo como forma social dominante é gestado a partir de certas causalidades socioespaciais que constituem o combustível para mudanças desde a raiz, o que envolve "uma política engatada ao lucro" (HOBSBAWM, 2010, p. 64), no caso da Inglaterra, e a figura ativa de indivíduos revolucionários, no caso da França.

Ou seja, tais movimentos ocorreram sob influência direta e indireta da dinâmica econômica inglesa, mas também do parasitismo relutante da nobreza francesa ante as ideias liberais que somente encontraram campo prático com a supressão do Ancien Regime. Do ponto de vista geográfico é a partir da Europa ocidental e dos Estados Unidos que tal modo de produção toma forma e passa a exercer controle e/ou a desarticular e a verter para a sua lógica territórios pautados por dinâmicas produtivas diferenciadas ${ }^{21}$. E a mutação de leis, políticas e costumes acompanha o vigor socioprodutivo daquele capital mais desenvolvido que dali surgia: "na Inglaterra, quando

21 Por exemplo: Marx (2008, v.l, p.274) ressalta que "o trabalho dos negros nos estados meridionais da América do Norte preservava certo caráter patriarcal enquanto a produção se destinava principalmente à satisfação direta das necessidades. Na medida, porém, em que a exportação de algodão se tornou interesse vital daqueles estados, o trabalho em excesso dos pretos e o consumo de sua vida em 7 anos (sic) de trabalho tornaram-se partes integrantes de um sistema friamente calculado". 


\section{PONDERAÇÕES ACERCA DA IDEOLOGIA NO E DO ESPAÇO TURÍSTICO Rodrigo Meira Martoni}

deixaram de queimar feiticeiras, começaram a enforcar falsificadores de bilhetes de banco" (MARX, 2001, p. 869).

A primeira questão a ser ressaltada é que somente o capitalismo possui as efetivas condições para que os valores de uso sejam largamente tragados como mercadorias. Obviamente que mercadorias e dinheiro circulavam entre os fenícios, os gregos, os romanos, mas, desconsiderando aqui as díspares características de cada uma dessas sociedades, o fato é que o valor para a troca não penetrava inteiramente as transações e relações sociais. Observa-se, no caso das comunidades eslavas, por exemplo, que "o dinheiro e a troca que o condiciona não aparecem ou aparecem muito pouco no interior das comunidades singulares, mas em suas fronteiras, no intercâmbio com outras comunidades [...]" (MARX, 2011, p. 56).

Se havia aí o papel do dinheiro entre sociedades diferentes, mas não em seu interior, as relações de troca, quando passam a mediar o convívio entre os seus membros, empreendem substantivas mudanças, pois elas requerem uma divisão do trabalho mais desenvolvida e abrem campo para que produtos sejam feitos ou serviços sejam prestados para satisfazer a necessidade de ampliação do dinheiro. Quando o valor para a troca alcança o valor de uso e o domina, não mais somente pelo dinheiro ampliado na circulação e tão pouco pela necessidade de um bem, mas pelo e para o capital com o trabalho em excesso, está posta a condição essencial para que a mercadoria permeie as relações sociais. Enquanto valores de uso, nada há de oculto nos produtos do trabalho. Enquanto trabalho qualitativo ou concreto e, portanto, como atividade associada para o bem comum, também não há qualquer mistério no trabalho. Diz Marx (2008, p. 94):

[...] a forma mercadoria e a relação de valor entre os produtos do trabalho, a qual caracteriza essa forma, nada têm a ver com a natureza física desses produtos nem com as relações materiais dela decorrentes. Uma relação social definida, estabelecida entre os homens, assume a forma fantasmagórica de uma relação entre coisas. Chamo a isso de fetichismo, que está sempre grudado aos produtos do trabalho, quando são gerados como mercadorias. É inseparável da produção de mercadorias.

Feita novamente a menção de que o capitalismo não é algo natural, mas uma construção social facilmente discernível de outros momentos gerais da organização socioprodutiva e, portanto, modificável, a primeira questão relaciona-se ao controle dos produtos sobre os produtores ou a essa imposição fantasmagórica sobre os sujeitos. Do nascimento até a morte, os indivíduos se deparam com os resultados de suas próprias atividades como algo que possui leis próprias, manifestadamente pela necessidade de reprodução das coisas por si mesmas e de relações que propiciem a produção, reprodução e acumulação de capital. A tais interações, todos e todas se enquadram para poder se manter, sendo que os questionamentos que tendem a se levantar contra tais relações estranhas é desqualificado por 


\section{PONDERAÇÕES ACERCA DA IDEOLOGIA NO E DO ESPAÇO TURÍSTICO}

Rodrigo Meira Martoni

uma ideologia que o situa como relação eterna e universal: “[...] a propriedade sobre o trabalho objetivado [...] é reconhecida como relação jurídica, como condição universal da produção e [posto] como expressão da vontade universal" (MARX, 2011, p. 424), naturalizando algo que é social.

Mesmo que os sujeitos, do ponto de vista individual, venham a conhecer os fundamentos dessa condição e da razão de ser dos produtos do trabalho, por si mesmos ou pelo modo em que estão inseridos como representantes do trabalho ou mesmo do capital, eles não podem alterá-las. O papel social e não o pessoal referente aos dois representantes citados é o que deve ser considerado aqui: de nada adianta o capitalista ter total consciência de que a falta de equivalência entre o trabalho total e a remuneração do seu empregado é uma injustiça se dela ele depende para continuar a personificar o capital. Em se tratando do produtor-direto, a consciência individual é impotente sem as circunstâncias objetivas e a consciência de classe, mas, mesmo que essa consciência seja concreta, isso não o isenta da relação objetal de compra e venda em seu cotidiano. De uma forma geral, o trabalhador atrelado à universalização de relações reificadas faz com que a ele seja "permitido ter tanto para que queira viver, e [ao mesmo tempo, seja] permitido querer viver para ter" (MARX, 2010, p. 142).

Verifica-se que a inovação tecnológica posta essencialmente pela competitividade entre empresas e nações em um sentido macro e dependente do desenvolvimento cientifico é um fato que envolve uma questão de manutenção e busca incessante pelo poder econômico e político em variados setores. Mas trata-se de uma concretização somente possível pelo trabalho social. O fato é que, estando as forças produtivas sob o comando do capital, o qual não pode sobreviver se não se empenhar em diminuir a parte do trabalho necessário ou mesmo eliminá-lo em um espaço para se criar em outro sob condições mais vantajosas, são os próprios sujeitos sociais que criam os elementos que irão liquidar suas atividades laborativas e, portanto, conforme coloca Eagleton (1997, p. 100), "o capitalismo sobrevive apenas por um desenvolvimento incansável das forças produtivas". Os serviços e, nesse contexto, o turismo, que desponta como setor econômico ou "indústria mundial" em meados do século XX em diversas realidades, é uma das consequências do capital para absorver contingentes e aproveitá-los em frentes de trabalho que particularizam o capital daí advindo.

Em relação a esse poder objetal, uma exemplificação pontual: o turismo de eventos e entretenimento não foi apenas o resultado de uma boa ideia que se viu frustrada pouco tempo depois em Flint, Michigan, EUA, mas foi a condição material criada pela General Motors, em meados da década de 1980, ao transladar sua montadora para o México e demitir cerca de trinta mil funcionários em uma única cidade, situação essa efetivada pela imposição de ascensão do capital (ou a sua própria natureza) a partir das 


\section{PONDERAÇÕES ACERCA DA IDEOLOGIA NO E DO ESPAÇO TURÍSTICO Rodrigo Meira Martoni}

condições mais apropriadas para a extração de valor a mais no país vizinho $^{22}$. Ocorre que a referida montadora jamais poderia ter sido implantada e operacionalizada somente com a presença e atuação de meia dúzia de diretores. $\mathrm{O}$ trabalho social que a gerou a partir de uma massa de valor a mais acumulado e que buscava valorizar-se, criou o capital que ali operou enquanto tal atividade produtiva o atendeu, sendo que essa mesma criação foi quem minou a possibilidade de trabalho dos sujeitos sem que eles nada pudessem fazer: o produto volta-se contra o produtor.

Conforme aponta Eagleton (1997, p. 82): “os homens e as mulheres fazem produtos que depois escapam a seu controle e determinam suas condições de existência. Uma flutuação na bolsa de valores pode significar desemprego para milhares". O que toma a frente é a relação entre coisas quando as interações humanas são determinadas e condicionadas pelos produtos do trabalho, sendo que, uma vez que as mercadorias (materiais e imateriais) escapam pelos dedos dos produtores, essa força deixa de ser reconhecida como resultado de circunstâncias atreladas a projetos humanos. Por isso, Marx (2008, v.I, p.102) relata que no capitalismo "o processo de produção domina o homem, e não o homem o processo de produção". A naturalização das relações sociais capitalistas associada a universalização desse modo de produção que, para a mente reificada, sempre existiu, faz com que os sujeitos pensem e ajam sem conhecer de onde vem e para onde vão. Circunscritos a um poder objetal, têm suas existências primordialmente a ele justificadas, o que gera toda a sorte de incertezas, desigualdades, conflitos e extremismos.

\section{Considerações finais}

A forma de produção material e imaterial da vida social, por ela mesma e com as devidas e necessárias associações com a ideologia dominante (incluindo aí as planificações possíveis vindas de cima para baixo) é mantenedora das ideias que circulam e se aprofundam "cientificamente" nessas leis possíveis, "naturais" e "eternas". Tais ideias, ao não se aterem ao fenômeno da reificação, ou seja, de que elas são entrelaçadas, agarradas ou embrenhadas à produção de mercadorias para a ascensão direta e/ou indireta do capital, acabam restritas a uma circularidade descritiva que tem começo nas formas aparentes, alcançam o céu pela subjetividade e retornam à terra acentuando ou deixando as dinâmicas coisificadas em sua livre marcha.

Uma frase popular que é repetida por muitos grupos sociais serve de exemplo da reificação: o dinheiro faz o dinheiro. Ela desconsidera que o trabalho social se impõe entre o dinheiro inicialmente investido para se conseguir mais dinheiro (o dinheiro que é capital) e, quando tal atividade

22 Acerca de Flint, ver documentário de Michael Moore intitulado “Roger e Eu” (1989). 


\section{PONDERAÇÕES ACERCA DA IDEOLOGIA NO E DO ESPAÇO TURÍSTICO \\ Rodrigo Meira Martoni}

gera acessórios (os quais também podem ser o ponto de partida), como, por exemplo, o dinheiro que produz juros, os ganhos provenientes de rendas ou do capital financeiro, esses são vistos como resultados do empenho individual, mas nunca de interações sociais: "para a economia vulgar, que quer representar o capital como fonte autônoma e de criação do valor, essa forma $\left[\mathrm{D}-\mathrm{D}^{+}\right]$é naturalmente abençoada, pois nela a fonte do juro não é mais reconhecida, nela o resultado do processo capitalista de produção [...] adquire uma existência autônoma" (LUKÁCS, 2012, p. 213). Vale aqui ressaltar que tal noção desempenha importante papel para a "praxis fetichizada" (KOSIK, 1976, p. 15) do dia a dia.

Sabe-se que o capitalismo somente pode se manter com novas e outras forças produtivas e, no caso do turismo, ele depende de realidades socioespaciais e de seus atributos concretos. O desfrute de uma praia, o terreno aprazível em uma montanha utilizado para um acampamento, os desejos de ir e vir e de se conhecer novos lugares, culturas e histórias, o prazer de uma noite confortável e de um transporte seguro, a significação de uma cidade e do seu patrimônio para os sujeitos que a vivenciaram ou a vivenciam, tudo isso, enquanto valores de uso, nada têm de misterioso. E o trabalho encarado como fim para as necessidades próprias e do outro (e não como fim para o capital), situado, nesse caso, como expressão da hospitalidade que se faz presente no contato que enriquece a experiência humana, também não carrega nenhum elemento que foge à compreensão.

Mas, a absorção de particularidades socioespaciais como mercadorias e, essencialmente, o trabalho como tal, tende a impedir essa relação humana direta de uma forma dupla: as objetividades e os recursos da natureza assim compreendidos e os sujeitos que passam a se mover e são movidos por elas associam-se de forma coisificada, onde as primeiras somente são consideradas em sua significação histórica, cultural ou essencial à vida quando se tornam "veículos materiais [e imateriais]" (MARX, 2008, v.I, p.58) para a troca. Paralelamente, os sujeitos que incorporam valor a valores de uso através do trabalho no turismo movemse por uma ideologia que se origina de sua própria atividade produtiva reificada.

Ouriques (2005, p. 52) aponta que o espetáculo ou a sociedade do parecer de que fala Guy Debord (1997) é “o fetichismo da mercadoria potencializado". Compreendemos que o espetáculo é funcional e essencial ao fetiche enquanto expediente ideológico superestrutural, mas a reificação mesma, conforme apontado, é uma dimensão que está presa às relações sociais de produção enquanto essas forem postas em prol da acumulação privada sem fim, ou seja, da mercadoria (e não de valores de uso que atendem as carências e necessidades humanas). As exemplificações levantadas por Ouriques acerca do turismo em assentamentos do Movimento dos Trabalhadores Desempregados do Rio Grande do Sul, em comunidades da Índia e nas favelas do Rio de Janeiro, ou mesmo a menção feita em relação ao turismo nas townships, significam a tentativa de 


\section{PONDERAÇÕES ACERCA DA IDEOLOGIA NO E DO ESPAÇO TURÍSTICO}

Rodrigo Meira Martoni

populações se inserirem de alguma forma na produção com o intuito de serem assimiladas por um mercado turístico, incluindo aí agências, promotores de eventos, alojamentos, empresas de transporte. A possível assimilação de realidades específicas como valores ou como unidades a serviço da "grande indústria do turismo" irá fatalmente posicioná-las como "organização capitalista [a qual] impinge-lhe os seus ritmos [e] introduz com a sua lógica implacável o relógio-de-ponto e os seus padrões [...]" (NETTO, 1981, p. 82).

No caso das comunidades do Apartheid, conforme ressaltado, havendo controle sobre o que será feito, há alienação. E havendo todo um conjunto de atividades pelo e para o valor se realizar, há reificação. Ouro Preto e as suas especificidades patrimoniais harmônicas, citada como exemplo de expressão de uma ideologia que associa inversão e ilusão, possui toda uma instrumentalização do turismo já reificada em termos gerais, sendo as formas de ideologia superestrutural os apêndices de todo um aparato socialmente operacionalizado para a chamada hospitalidade produtiva. Isso porque, tal localidade como patrimônio mundial da humanidade associado não propriamente à preservação, mas esta como componente imprescindível do turismo e do mercado imobiliário, está inserida em uma “[...] forma mercantil como forma universal, [sendo que] mesmo quando considerada por si, exibe uma imagem diferente do que como fenômeno particular, isolado e não dominante" (LUKÁCS, 2012a, p.196-197).

Haja vista que cada espaço tem a sua configuração, mas o turismo, em termos gerais, é algo universal quando posto como mediação para a produção e reprodução do capital, essa atividade tende a promover relações laborativas-produtivas que se impõem a depender de atributos comercializáveis. É possível que alguém leia Eduardo Galeano e vá passear em Ouro Preto podendo fazer uma análise diferenciada dos guias turísticos ao estabelecer conexões reais. Contudo, o individual somente é parâmetro para a análise socioespacial quando se situa em práticas amplas, as quais jamais podem estar desvinculadas da averiguação acerca da categoria valor em sua forma dominante atual e do fato de que a produção é a produção capitalista e independe, do ponto de vista individual e não coletivo, daqueles consumidores mais conscientes.

Eliminar isso do campo analítico é alimentar a ilusão de que pode haver um "turismo com o território" no sentido de compreensão da totalidade por tipos ideais weberianos de turismo e de planificação do espaço (o turismo histórico, ecológico, etc). Esse somente conformaria uma prática social para si mesma quando considerada como valor de uso, o que seria possível em uma realidade social particularizada por não inscrever a riqueza como propriedade privada e, portanto, onde os resultados do trabalho também seriam socializados. Ou seja: um espaço que se corporifica tão somente como esperança, valendo-se das palavras utilizadas por Harvey (2009), por ultrapassar o tempo presente ou a "pré-história" da humanidade (MARX). 


\section{PONDERAÇÕES ACERCA DA IDEOLOGIA NO E DO ESPAÇO TURÍSTICO Rodrigo Meira Martoni}

Com tais observações, tenta-se apontar uma resposta sempre provisória à questão colocada em relação ao poder da ideologia e de onde ela efetivamente provém: a atividade de trabalho, na qual e perante a qual não se percebe as relações sócio-humanas que operam para que algo possa ser desfrutado, não pelo desfrute, mas pelo objeto, constitui a relação capital versus trabalho. Considerar a ideologia dominante e aquela combativa na dimensão superestrutural é tarefa primordial, mesmo porque essa última pode lançar luz em tal interação, incluindo 1) o "espetáculo" que condiz com a ideologia nos espaços turísticos; e 2) a naturalização do capitalismo universalizado que faz parte da "investida desistoricizante" de que fala Eagleton (1997, p.62) e que corresponde àquela ideologia que "congela a história [...] apresentando-a como espontânea, inevitável e, assim, inalterável".

Mas essa compreensão não irá possibilitar um "turismo no território" sem suprimir a relação capital versus trabalho naquelas realidades em que tal interação já dá os seus frutos objetais. A ideologia que emana do espaço tornado turístico por novas frentes lançadas por capitais em busca de lucros e/ou rendas e a possível desarticulação de lógicas produtivas mais simplificadas (que, aliás, até podem persistir e atender a "grande indústria do turismo"), somente pode ser enfrentada por outra organização socioprodutiva. Enquanto isso, o turismo pode ser compreendido como um importante mecanismo de alienação e reificação, tanto pela pelas formas socioespaciais como pela maneira que é produzido.

\section{Referências}

ANTUNES, Ricardo Luis Coltro. Os sentidos do trabalho: ensaio sobre a afirmação e a negação do trabalho. (Mundo do Trabalho). 2.ed. São Paulo: Boitempo, 2009. 287p.

BANDEIRA, Manuel. Guia de Ouro Preto. Rio de Janeiro: Ediouro, 2000. $118 \mathrm{p}$.

BARBOSA, Ycarim Melgaço. O despertar do turismo: um olhar crítico sobre os não-lugares. (Série Turismo). 2.ed. São Paulo: Aleph, 2001. 101p.

CORIOLANO, Luzia Neide M. T.; ALMEIDA, Humberto Marinho de. O turismo no nordeste brasileiro: dos resorts aos núcleos de economia solidária. In: Colóquio Internacional de Geocrítica, 9, 2007, Porto Alegre, UFRS, p.1-19. Disponível em: <http://www.ub.edu/geocrit/9porto/luzianei.htm>. Acesso em: 20 out. 2013.

COSTA, Everaldo Batista da. Totalidade urbana e totalidade-mundo: as cidades coloniais barrocas frente a patrimonialização global. 2011. 445f. 


\section{PONDERAÇÕES ACERCA DA IDEOLOGIA NO E DO ESPAÇO TURÍSTICO Rodrigo Meira Martoni}

Tese (Doutorado - Programa de Pós-Graduação em Geografia Humana) Faculdade de Filosofia, Letras e Ciências Humanas da Universidade de São Paulo. Disponível em:

http://www.teses.usp.br/teses/disponiveis/8/8136/tde-14032011104656/pt-br.php. Acesso em: 26 ago. 2013.

Direito de resposta de Leonel Brizola à Rede Globo: A verdade seja dita. Jornal Nacional, Rio de Janeiro: Rede Globo, 1994. Disponível em: https://www.youtube.com/watch?v=C3FqswEuNUc. Acesso em: $10 \mathrm{fev}$. 2014.

DEBORD, Guy. A sociedade do espetáculo. Tradução de Estela dos Santos Abreu. Rio de Janeiro: Contraponto, 1997. 237p.

EAGLETON, Terry. Ideologia. Tradução de Silvana vieira e Luís Carlos Borges. São Paulo: Boitempo, 1997, 203p.

ELLUL, Jacques. La pensée marxiste. Paris: La Table Ronde, 2012, 346p.

HARVEY, David. Espaços de esperança. Tradução de Adail Ubirajara Sobral e Maria Stela Gonçalves. 3.ed. São Paulo: Loyola, 2009. 382p.

HOBSBAWM, Eric J. A era das revoluções: 1789-1848. Tradução de Maria Tereza Teixeira e Marcos Penchel. 25.ed. São Paulo: Paz e Terra, 2010. 535p.

IANNI, Octávio. Capitalismo, violência e terrorismo. Rio de Janeiro: Civilização Brasileira, 2004. 381p.

IHA, Clara. O desafio da mão de obra. Anuário Exame, São Paulo, p. 76-77, abril, 2007.

INSTITUTO DO PATRIMÔNIO HISTÓRICO E ARTÍSTICO NACIONAL IPHAN (Brasil). Cartas Patrimoniais. 2.ed. Organização de Isabelle Cury. Rio de Janeiro: IPHAN, 2000. 384p.

KNAFOU, Remy. Turismo e Território: por uma abordagem científica do turismo. In: RODRIGUES, Adyr A.B. Turismo e geografia: reflexões teóricas e enfoques regionais. São Paulo: Ed. HUCITEC, 1996, p. 62-74.

KOSIK, Karel. A dialética do concreto Tradução de Célia Neves e Alderico Toríbio. 2.ed. Rio de Janeiro: Paz e Terra, 1976.

LEFEBVRE, Henri. A revolução urbana. Tradução de Sérgio Martins. Belo Horizonte: Ed. UFMG, 1999. 176p. 
PONDERAÇÕES ACERCA DA IDEOLOGIA NO E DO ESPAÇO TURÍSTICO

Rodrigo Meira Martoni

Espaço e política. Tradução de Margarida Maria de Andrade e Sérgio Martins. Belo Horizonte: Ed UFMG, 2008. 190p.

LÉNINE, Vladimir Ilitch. Materialismo e Empiriocriticismo: notas críticas sobre uma filosofia reaccionária. Lisboa: Avante, 1892. 339p.

LUKÁCS, György. Prolegômenos para uma ontologia do ser social: questões de princípios para uma ontologia hoje tornada possível. Tradução de Lya Luft e Rodnei Nascimento. São Paulo: Boitempo, 2010. 414p.

LUKÁCS, György. História e consciência de classe: estudos sobre a dialética marxista. Tradução de Rodnei Nascimento. 2.ed. São Paulo: WMF Martins Fontes, 2012.

MARX, Karl; ENGELS, Friedrich. A Ideologia Alemã: crítica da novíssima filosofia alemã... Organização, tradução, prefácio e notas de Marcelo Backes. Rio de Janeiro: Civilização Brasileira, 2007. 643p.

MARX, Karl. O Capital: crítica da economia política, livro I, volume I. Tradução de Reginaldo Sant'Anna. 26.ed. Rio de Janeiro: Civilização Brasileira, 2008.

O Capital: crítica da economia política, livro III, volume VI. Tradução de Reginaldo Sant' Anna. Rio de Janeiro: Civilização Brasileira, 2008 .

O Capital: crítica da economia política, livro I, volume II. Tradução de Reginaldo Sant'Anna. 17. ed. Rio de Janeiro: Civilização Brasileira, 2001.

. Grundrisse: manuscritos econômicos de 1857-1858: esboços da crítica da economia política. Supervisão editorial de Mario Duayer; tradução de Mario Duayer e Nélio Schneider. São Paulo: Boitempo, 2011.

Manuscritos econômico-filosóficos. Tradução de Jesus Ranieri. São Paulo: Boitempo, 2010. 191p.

MASCARO, Alysson Leandro. Estado e forma política. São Paulo: Boitempo, 2013. 132p.

MÉSZÁROS, István. Para além do capital. Tradução de Paulo Cezar Castanheira e Sérgio Lessa. São Paulo: Boitempo, 2006. 1102p. 
O desafio e o fardo do tempo histórico: o socialismo no século XXI. Tradução de Ana Cotrim e Vera Cotrim. São Paulo: Boitempo, 2007. 396p.

O poder da ideologia. Tradução de Paulo Cezar Castanheira. São Paulo: Boitempo, 2004. 566p.

MOORE, Michael. Roger e Eu. Manaus: Warner Bros Entertainment. 1989. 1 DVD (90 min.).

NETTO, José Paulo. Capitalismo e reificação. São Paulo: Livraria Editora Ciências Humanas, 1981. 87p.

OURIQUES, Helton Ricardo. A produção do turismo: fetichismo e dependência. Campinas: Alínea, 2005. 159p.

POZZER, Márcio Rogério Olivato. Políticas públicas para o patrimônio cultural na América Latina: a experiência brasileira e a equatoriana e o papel do Banco Interamericano de Desenvolvimento. 2011. 153 p. Dissertação (Mestrado - Programa de Pós-Graduação em Integração da América Latina) - Universidade de São Paulo. Disponível em: http:/ / www.teses.usp.br/teses/disponiveis/84/84131/tde-09102012101928/pt-br.php. Acesso em: 05 maio.2014.

RICHEZ, Jean-Claude; STRAUSS, Léon. Un temps nouveau pour les ouvriers: les congés payés (1930-1960). In: CORBAIN, Alain (Coord.) L'avènement des loisirs, 1850-1960. Paris: Aubier, 1995, p. 491-543.

SANTOS FILHO, João dos. Ontologia do Turismo. Caxias do Sul, RS: EDUCS, 2005. 79p.

SIMÃO, Maria Cristina Rocha. Preservação do patrimônio cultural em cidades. Belo Horizonte: Autêntica, 2006. 125p.

SOUZA, Renato Santos de. Entendendo a questão ambiental: temas de economia, política e gestão do meio ambiente. Santa Cruz do Sul: Edunisc, 2000. 461p. 